\title{
Xylella fastidiosa Endoglucanases Mediate the Rate of Pierce's Disease Development in Vitis vinifera in a Cultivar-Dependent Manner
}

\author{
Brian Ingel, ${ }^{1}$ Daniel R. Jeske, ${ }^{2}$ Qiang Sun, ${ }^{3}$ Joseph Grosskopf, ${ }^{3}$ and M. Caroline Roper ${ }^{1,+}$ \\ ${ }^{1}$ Department of Microbiology and Plant Pathology, University of California, Riverside, CA 92521, U.S.A. \\ ${ }^{2}$ Department of Statistics, University of California, Riverside, CA 92521, U.S.A. \\ ${ }^{3}$ Department of Biology, University of Wisconsin, Stevens Point, WI 54481, U.S.A.
}

Accepted 14 June 2019.

\begin{abstract}
Xylella fastidiosa is a gram-negative bacterium that causes Pierce's disease (PD) in grapevine. $X$. fastidiosa is xylemlimited and interfaces primarily with pit membranes (PMs) that separate xylem vessels from one another and from adjacent xylem parenchyma cells. PMs are composed of both pectic and cellulosic substrates, and dissolution of PMs is facilitated by $X$. fastidiosa cell wall-degrading enzymes. A polygalacturonase, which hydrolyzes the pectin component of PMs, is required for both movement and pathogenicity in grapevines. Here, we demonstrate that two $X$. fastidiosa $\beta-1,4-$ endoglucanases (EGases), EngXCA1 and EngXCA2, also play a role in how $X$. fastidiosa interfaces with grapevine PMs. The loss of EngXCA1 and EngXCA2 in tandem reduces both $X$. fastidiosa virulence and population size and slows the rate of PD symptom development and progression. Moreover, we demonstrate that single and double EGases mutants alter the rate of $P D$ progression differently in two grapevine cultivars, Cabernet Sauvignon and Chardonnay, and that Chardonnay is significantly more susceptible to PD than Cabernet Sauvignon. Interestingly, we determined that there are quantitative differences in the amount of fucosylated xyloglucans that make up the surface of PMs in these cultivars. Fucosylated xyloglucans are targets of the $X$. fastidiosa EGases, and xyloglucan abundance could impact PM dissolution and affect PD symptom development. Taken together, these results indicate that $X$. fastidiosa EGases and the PM carbohydrate composition of different grape cultivars are important factors that influence PD symptom development and progression.
\end{abstract}

Keywords: cell wall-degrading enzymes, grapevine cultivar, pit membrane, xylem

${ }^{\dagger}$ Corresponding author: M. C. Roper; caroline.roper@ucr.edu

Funding: This work was supported by a grant awarded to C. Roper from the California Department of Food and Agriculture Pierce's disease and Glassy-Winged Sharpshooter Board (grant number 16-0510-SA) and the United States Department of Agriculture National Institute of Food and Agriculture Hatch Project 1002710.

*The $\boldsymbol{e}$-Xtra logo stands for "electronic extra" and indicates that three supplementary figures and six supplementary tables are published online.

The author(s) declare no conflict of interest.

(c) 2019 The American Phytopathological Society
Xylella fastidiosa is a gram-negative, xylem-limited bacterium that causes disease in many economically important crops across several continents. $X$. fastidiosa strains have been assigned to different subspecies that generally align with host specificity (Almeida and Nunney 2015; Schuenzel et al. 2005). In the United States, X. fastidiosa subsp. fastidiosa is the implicated causal agent of Pierce's disease (PD) of grapevine. In Central and South America, the citrus and coffee industries have been severely affected by X. fastidiosa subsp. pauca, which causes citrus variegated chlorosis and coffee leaf scorch, respectively (Chang et al. 1993; Li et al. 2001). Recently, $X$. fastidiosa subsp. pauca has been implicated as the causal agent of olive quick decline syndrome in southern Italy (Saponari et al. 2013) and is one of the first reports of $X$. fastidiosa in Europe. Symptoms of PD include leaf scorching, irregular lignification (green islands) and matchstick petioles, followed by fruit desiccation, cordon dieback, and vine death (Goheen and Hopkins 1988; Purcell 1986; Stevenson et al. 2005; Varela 1996). X. fastidiosa resides exclusively within the xylem of plant hosts, with symptoms similar to, but not exactly like, water stress imparted by xylem disruption (McElrone et al. 2001 and 2003; Thorne et al. 2006a). X. fastidiosa is transmitted by xylemfeeding hemipteran leafhopper insects, including Graphocephala atropunctata, the blue-green sharpshooter, and Homalodisca vitripennis, the glassy-winged sharpshooter (Hill and Purcell 1995).

PD symptom severity is highly correlated with the ability of the bacterium to proliferate within the xylem and systemically colonize the grapevine host (Chatterjee et al. 2008a; Sun et al. 2011). X. fastidiosa is strictly limited to the xylem tissue, a nutrient-poor niche with few available carbon sources dissolved as solutes in the xylem sap or the primary cell wall material that comprises pit membranes (PMs). The xylem in grapevines is built of many interconnected vessels that are finite, but variable in length, and vessels rarely span the entire length of the vine (Thorne et al. 2006b; Tyree and Zimmermann 2002). Xylem vessels are connected to each other by scalariform-bordered pits that contain PMs (Brett and Waldron 1996). PMs are porous primary cell wall-middle lamella structures that allow water and small solutes to pass between vessels but also serve to prevent the movement of disruptive elements such as air embolisms or pathogens (Stevenson et al. 2004; Tyree and Zimmermann 2002). X. fastidiosa must traverse PMs to move systemically within the grapevine xylem. However, grapevine PM pores have a diameter of 5 to $20 \mathrm{~nm}$, and the rod-shaped $X$. fastidiosa cells, having a width of 250 to $500 \mathrm{~nm}$ and length of 1,000 to $4,000 \mathrm{~nm}$, are too large to passively move through

1402 / Molecular Plant-Microbe Interactions 
these small pores (Buchanan et al. 2000; Choat et al. 2004; Mollenhauer and Hopkins 1974). Grapevine PMs are composed of cellulose microfibrils, xyloglucan (hemicellulose), and pectin (Brett and Waldron 1996; Dickison 2007). These polysaccharides can serve as the substrates of cell wall-degrading enzymes (CWDEs) produced by pathogenic bacteria and fungi as these invading pathogens navigate and proliferate within the xylem (Bateman 1976; Hématy et al. 2009; Popeijus et al. 2000; Ward et al. 1989). The X. fastidiosa genome encodes several genes annotated as CWDEs, including one polygalacturonase (PG), three $\beta$-1,4-endoglucanases (EC 3.2.1.4) (EGases), one cellobiohydrolase, and one xylanase (Simpson et al. 2000; Van Sluys et al. 2003). PGs facilitate the hydrolytic cleavage of pectin, and an $X$. fastidiosa mutant lacking one PG (PglA) failed to move beyond the point of inoculation and did not induce PD symptoms, indicating that the PG is required for systemic colonization (Roper et al. 2007).

EGases are hydrolytic enzymes that cleave $\beta-1,4$ glycosidic linkages, such as those found in cellulose, and the crosslinking glycans (hemicellulose), which are both constituents of the vascular plant cell wall (Buchanan et al. 2000; Larner 1960). Of the three annotated $X$. fastidiosa EGases, EngXCA2 (PD1851) is the only prototypical EGase composed of an Nterminal glycosyl hydrolase domain and a C-terminal carbohydrate binding module. $X$. fastidiosa EngXCA2 hydrolyzes cellulosic substrates, such as carboxymethylcellulose (CMC) and xyloglucan (Pérez-Donoso et al. 2010). EngXCA1 (PD1856) has a predicted N-terminal glycosyl hydrolase domain homologous to that of EngXCA2 and a predicted Cterminal expansin domain. The expansin domain is notable because expansins are considered to be plant proteins. Expansins are nonenzymatic and bind to cellulose and hemicellulose to facilitate cell wall expansion during plant cell growth and likely were acquired from plants via cross-kingdom horizontal gene transfer (Cosgrove 2000; Nikolaidis et al. 2014). Interestingly, with a few exceptions, expansins are found in genera of bacteria that dwell in plant xylem tissue, such as Bacillus, Clavibacter, Ralstonia, Xanthomonas, Pectobacterium, and Dickeya, suggesting that expansins are advantageous for bacteria inhabiting the xylem (Georgelis et al. 2014; Kerff et al. 2008; Tancos et al. 2018; Tovar-Herrera et al. 2018). The third EGase, Egl (PD2061), has a predicted N-terminal glycosyl hydrolase domain but does not have domains related to carbohydrate binding.

EGases are important enzymatic virulence factors for several bacterial phytopathogens. For necrotrophic bacteria, such as Pectobacterium (Erwinia) caratovorum, EGases contribute to virulence and nutrient acquisition by inducing soft rot (Barras et al. 1994; Walker et al. 1994). For bacteria with a significant xylem-dwelling phase, such as Pantoea stewartii subsp. stewartii, Ralstonia solanacearum, and Xanthomonas campestris pv. campestris, EGases play an important role in virulence and host colonization (Gough 1988; Mohammadi et al. 2012; Roberts et al. 1988; Saile et al. 1997). Moreover, it has been suggested that xylem-dwelling bacteria use EGases to degrade PMs as a means of acquiring nutrients (Fatima and SenthilKumar 2015; Pérez-Donoso et al. 2010; Pieretti et al. 2012).

The mechanisms by which $X$. fastidiosa acquires carbon in the xylem have not been fully elucidated, and it is unclear whether carbon released as a consequence of PM degradation is utilized by the bacterium as a nutrient source. In addition, differences in PD severity and symptom progression rate have been noted in different cultivars of Vitis vinifera, but little is known about the host physiological properties or bacterial molecular mechanisms underlying these observations. This study was structured to examine host PM composition as a factor in cultivar susceptibility, as well as to test the role of
$X$. fastidiosa EGases in plant colonization and disease symptom development. This work demonstrates that there are quantitative differences in the hemicellulosic component of PMs, namely the fucosylated xyloglucans, of two cultivars, Chardonnay and Cabernet Sauvignon, and that Chardonnay develops PD at a significantly faster rate than Cabernet Sauvignon. Furthermore, the virulence of an $X$. fastidiosa mutant lacking two of the EGases is severely impacted in both cultivars, but significantly more so in Cabernet Sauvignon. These results support our hypothesis that the composition of the hemicellulosic content of xylem PMs affects the rate of PD development and is one of the determinants of PD severity among grapevine cultivars. Collectively, two X. fastidiosa EGases (EngXCA1 and EngXCA2) also support bacterial growth in the xylem, suggesting EGases play a major role in nutrient acquisition in the xylem environment.

\section{RESULTS}

\section{Grapevine cultivar is a factor in rate and severity of PD symptom development.}

PD symptoms were monitored weekly for 20 weeks postinoculation (WPI), and observed PD symptom scores were used to generate a generalized estimating equations (GEE) model to compare PD symptom development in Chardonnay and Cabernet Sauvignon. From the GEE model, PD symptom development was divided into stages: early-stage PD (5 WPI), mid-stage PD (10 WPI), late-stage PD (15 WPI), and the endpoint of the experiment (20 WPI). Wild type-inoculated Chardonnay vines exhibited significantly higher PD symptom scores than wild type-inoculated Cabernet Sauvignon vines at early-, mid-, and late-stage PD and at the endpoint of the experiment (Fig. 1A). To further understand the rate of disease manifestation, the GEE model was used to assess differences in the rate of PD symptom development in Cabernet Sauvignon and Chardonnay by calculating the change in $\mathrm{PD}$ symptom score over time between early-stage PD and latestage PD (5 to $15 \mathrm{WPI}$ ) where symptom progression was linear (PD symptom progression rate). The PD symptom progression rate was significantly faster in Chardonnay than in Cabernet Sauvignon between early- and mid-stage PD ( 5 to 10 WPI), and between mid- and late-stage PD (10 to 15 WPI) (Table 1). However, wild-type titers at the point of inoculation (POI) and at 20 nodes distal to the POI were statistically similar in Chardonnay and Cabernet Sauvignon at the late stage of infection (Fig. 1B), indicating that symptom severity is decoupled from bacterial titer at this stage of disease. These trends were also seen in vines inoculated with $\triangle e n g X C A 1$, $\triangle e n g X C A 2$, or $\triangle e n g X C A 1 / 2$ (Table 1; Supplementary Fig. S1). All $P$ values, estimated mean differences, and statistical significance values are summarized in Supplementary Tables S1 and $\mathrm{S} 2$.

\section{The fucosylated xyloglucan component of xylem PMs differs between cultivars.}

Immunogold-scanning electron microscopy (SEM) was used to detect fucosylated xyloglucans in the surface layer of intervessel PMs in Cabernet Sauvignon and Chardonnay grapevines to determine whether there were quantitative differences between the two cultivars with regard to the fucosylated xyloglucan component of PMs. After immunogold labeling, relatively few gold particles were bound to Cabernet Sauvignon PMs (Fig. 1C), indicating that the surface layer is sparsely populated with fucosylated xyloglucans. Conversely, many gold particles were detected for Chardonnay PMs (Fig. 1D), indicating that the surface layer is densely populated with fucosylated xyloglucans. 
EGases are required for full virulence and affect rate of PD symptom development in a cultivar-dependent manner.

PD symptoms were monitored weekly over a 20 -week period, and observed PD symptom scores were used to generate a GEE model to compare PD symptom development at early-, mid-, and late-stage PD in wild type and EGases mutantinoculated vines (Supplementary Fig. S2). Subsequently, to better understand when EGases play the largest role, the GEE model was used to analyze the PD symptom progression rate between early- and late-stage PD (Tables 2 and 3). Cabernet Sauvignon vines inoculated with the $\triangle e n g X C A 1 / 2$ double mutant had significantly lower PD symptom scores than wild typeinoculated vines during all stages of PD and at the 20-week endpoint (Fig. 2A). Not only were symptoms less severe overall, but the PD symptom progression rate was significantly slower in $\triangle e n g X C A 1 / 2$-inoculated vines than in wild typeinoculated vines between early- and late-stage PD (Table 2), indicating that disease manifests more slowly in Cabernet Sauvignon vines inoculated with $\triangle e n g X C A 1 / 2$.

To better understand how individual EGases contribute to disease, we also tested single $\triangle e n g X C A 1$ and $\triangle e n g X C A 2 \mathrm{mu}-$ tants in planta. In Cabernet Sauvignon, $\triangle e n g X C A 1$-inoculated vines had significantly lower disease ratings than wild typeinoculated vines during early-stage $\mathrm{PD}$, but there were no differences in PD symptom scores during mid- and late-stage PD or at the endpoint (Fig. 2B). The PD symptom progression rate was not statistically different between $\triangle e n g X C A l$-inoculated
A

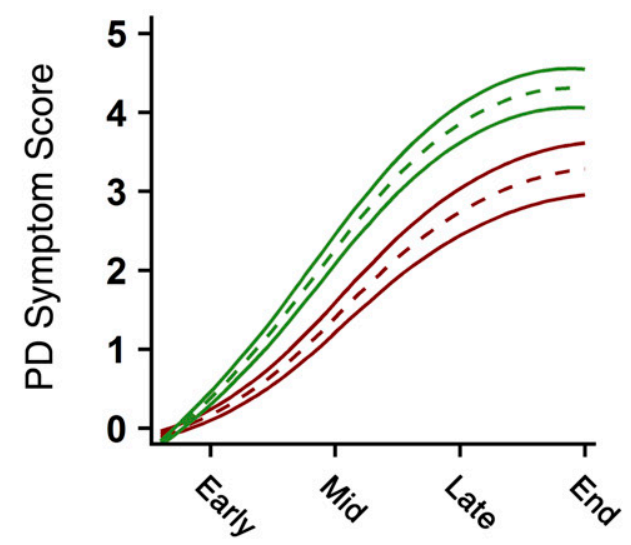

Stage of Pierce's Disease

Cabernet sauvignon

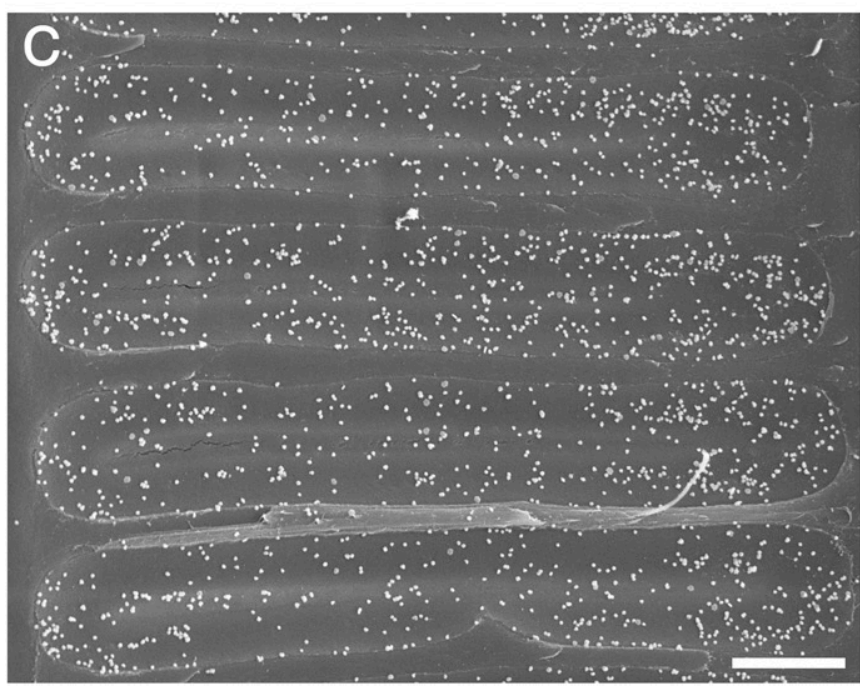

B

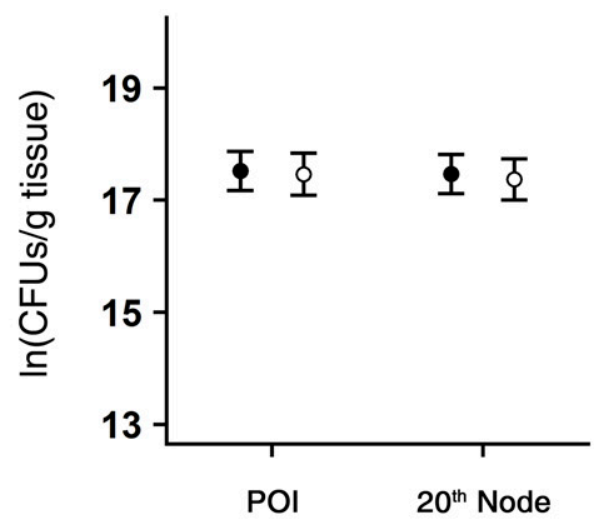

Colonization

Cabernet sauvignon
Chardonnay

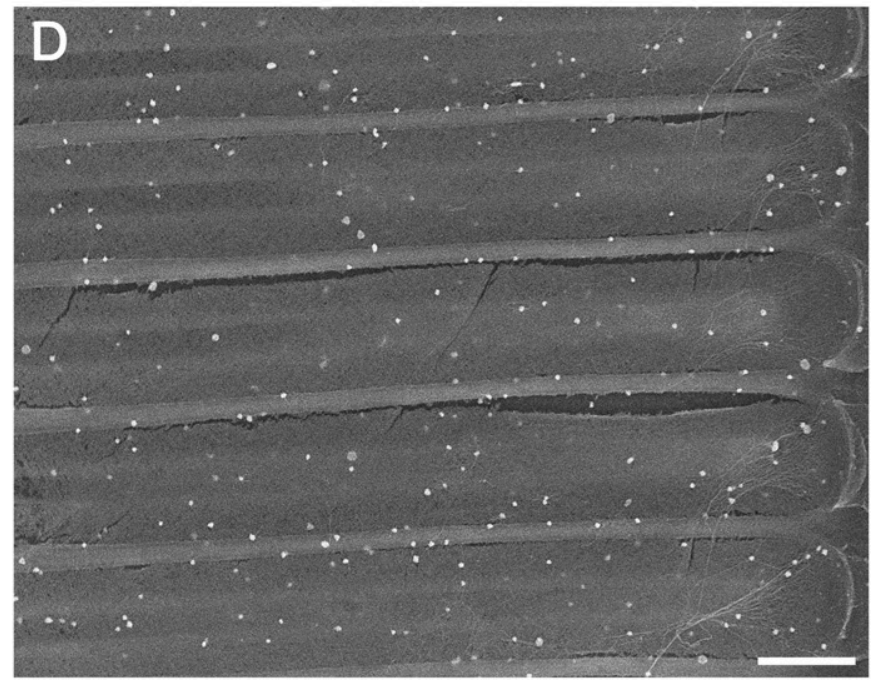

Fig. 1. Grapevine cultivar affects Pierce's disease (PD) symptom development and is mediated by differences in pit membrane (PM) composition. A, Overall PD symptom severity is greater in cv. Chardonnay (green) than in cv. Cabernet Sauvignon (red). A generalized estimating equations model was used to determine the estimated mean PD symptom scores per week (dashed lines) and to calculate $95 \%$ confidence intervals (solid lines). B, Xylella fastidiosa titers at the point of inoculation (POI) and at 20 nodes distal to the POI are not significantly different between Cabernet Sauvignon and Chardonnay. Colony forming units were normalized per gram of petiole tissue and transformed using the natural $\log (\ln )$. Statistical comparisons were made using a generalized negative binomial regression model. Error bars represent the standard error of the mean. C, Intervessel PMs of phosphate buffered saline (PBS)-inoculated Chardonnay have a dense distribution of silver-enhanced particles, indicating an abundance of fucosylated xyloglucans. D, Intervessel PMs of PBS-inoculated Cabernet Sauvignon have a moderate amount of silver-enhanced particles, indicating the presence of some fucosylated xyloglucans. Fucosylated xyloglucans were detected using the CCRC-M1 antibody, and intervessel PMs were imaged using immunogold-scanning electron microscopy. Scale bars are equal to $5 \mu$ m. 
vines and wild type-inoculated vines between early- and latestage $\mathrm{PD}$, indicating that although $\triangle e n g X C A 1$ initially elicits fewer symptoms in planta during the early stage, PD develops at the same rate as in wild type-inoculated vines, with symptom severity eventually equaling wild-type levels (Fig. 2B; Table 2). $\triangle e n g X C A 2$-inoculated vines had significantly higher PD symptom scores than wild type-inoculated vines during all stages of PD and the endpoint, and the PD symptom progression rate was faster in $\triangle e n g X C A 2$-inoculated vines than in wild type-inoculated vines between early- and late-stage PD (Fig. 2C; Table 2).
Similar to what was observed in Cabernet Sauvignon, Chardonnay vines inoculated with the $\triangle e n g X C A 1 / 2$ double mutant had significantly lower PD symptom scores than wild type-inoculated vines during all stages of PD (Fig. 2D), and the PD symptom progression rate in $\triangle e n g X C A 1 / 2$-inoculated vines was significantly slower than in wild type-inoculated vines between early- and mid-stage PD (Table 3). However, there was a notable difference in the rate at which PD symptoms developed in $\triangle e n g X C A 1 / 2$-inoculated Chardonnay compared with Cabernet Sauvignon. A continually lower rate of PD symptom progression was observed between early- and

Table 1. Comparison of the rate of Pierce's disease (PD) symptom progression in cv. Cabernet Sauvignon and cv. Chardonnay

\begin{tabular}{|c|c|c|c|c|c|c|c|c|}
\hline \multirow[b]{4}{*}{ Strain } & \multicolumn{8}{|c|}{ PD stage interval ${ }^{\mathbf{a}}$} \\
\hline & \multicolumn{4}{|c|}{ Early stage to mid stage } & \multicolumn{4}{|c|}{ Mid stage to late stage } \\
\hline & \multicolumn{2}{|c|}{ Rate } & \multicolumn{2}{|c|}{ Comparison } & \multicolumn{2}{|c|}{ Rate } & \multicolumn{2}{|c|}{ Comparison } \\
\hline & $\begin{array}{c}\text { Cabernet } \\
\text { Sauvignon }^{\text {b }}\end{array}$ & Chardonnay $^{\mathbf{c}}$ & $\begin{array}{c}\text { Rate } \\
\text { difference }^{\mathrm{d}}\end{array}$ & $P$ Value $^{\mathrm{e}}$ & $\begin{array}{c}\text { Cabernet } \\
\text { Sauvignon }^{b}\end{array}$ & Chardonnay $^{c}$ & $\begin{array}{c}\text { Rate } \\
\text { difference }^{\mathrm{d}}\end{array}$ & $P$ Value $^{\mathrm{e}}$ \\
\hline Wild type & 0.25 & 0.39 & $-0.14 \pm 0.02$ & $<0.0001 * * *$ & 0.27 & 0.32 & $-0.05 \pm 0.02$ & $0.0139 *$ \\
\hline$\triangle e n g X C A 1$ & 0.23 & 5 & $-0.12 \pm 0.04$ & $0.0013 * *$ & 0.28 & 0.40 & $-0.12 \pm 0.04$ & $0.0016 * *$ \\
\hline$\triangle e n g X C A 2$ & 0.32 & 0.39 & $-0.07 \pm 0.03$ & $0.0087 * *$ & 0.34 & 0.39 & $-0.05 \pm 0.03$ & $0.0525 \mathrm{~ns}$ \\
\hline$\triangle e n g X C A 1 / 2$ & 0.02 & 0.17 & $-0.15 \pm 0.02$ & $<0.0001 * * *$ & 0.07 & 0.30 & $-0.23 \pm 0.03$ & $<0.0001 * * *$ \\
\hline \multicolumn{9}{|c|}{$\begin{array}{l}\text { a Rates of PD symptom progression between early and mid stages of PD ( } 5 \text { to } 10 \text { weeks postinoculation) and between mid and late stages of PD (10 to } 15 \text { weeks } \\
\text { postinoculation). } \\
\text { b Estimated rate of PD symptom progression generated from the generalized estimated equations (GEE) model for each strain in Cabernet Sauvignon. } \\
\text { c Estimated rate of PD symptom progression generated from the GEE model for each strain in Chardonnay. } \\
\text { d Differences in the estimated rate of PD symptom progression (with standard error) in Cabernet Sauvignon and Chardonnay; negative values indicate that PD } \\
\text { progresses slower in Cabernet Sauvignon than in Chardonnay, and positive values indicate that PD progresses faster in Cabernet Sauvignon than in } \\
\text { Chardonnay. }\end{array}$} \\
\hline
\end{tabular}

Table 2. Comparison of the rate of Pierce's disease (PD) symptom progression for wild type and mutant strains in cv. Cabernet Sauvignon

\begin{tabular}{|c|c|c|c|c|c|c|}
\hline \multirow[b]{3}{*}{ Strain } & \multicolumn{6}{|c|}{ PD stage interval ${ }^{\mathbf{a}}$} \\
\hline & \multicolumn{3}{|c|}{ Early stage to mid stage } & \multicolumn{3}{|c|}{ Mid stage to late stage } \\
\hline & Rate $^{\mathbf{b}}$ & Rate difference $^{c}$ & $P$ Value $^{\mathrm{d}}$ & Rate $^{\mathbf{b}}$ & Rate difference $^{c}$ & $P$ Value $^{\mathrm{d}}$ \\
\hline Wild type & 0.25 & N/A & N/A & 0.27 & N/A & N/A \\
\hline$\triangle e n g X C A 1$ & 0.23 & $-0.02 \pm 0.03$ & $0.54 \mathrm{~ns}$ & 0.28 & $0.01 \pm 0.03$ & $0.64 \mathrm{~ns}$ \\
\hline$\Delta e n g X C A 2$ & 0.32 & $0.06 \pm 0.21$ & $0.023 *$ & 0.34 & $0.07 \pm 0.03$ & $0.0053 * *$ \\
\hline$\Delta e n g X C A 1 / 2$ & 0.02 & $-0.23 \pm 0.02$ & $<0.0001 * * *$ & 0.07 & $-0.20 \pm 0.02$ & $<0.0001 * * *$ \\
\hline
\end{tabular}

Table 3. Comparison of the rate of Pierce's disease (PD) symptom progression for wild type and mutant strains in cv. Chardonnay

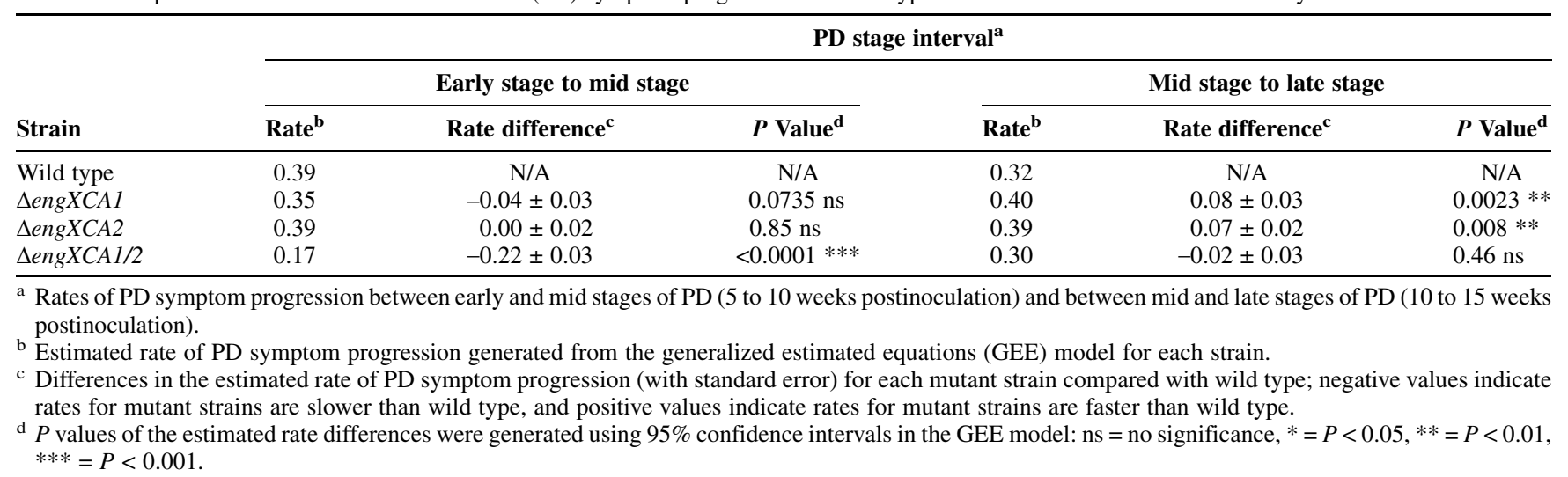




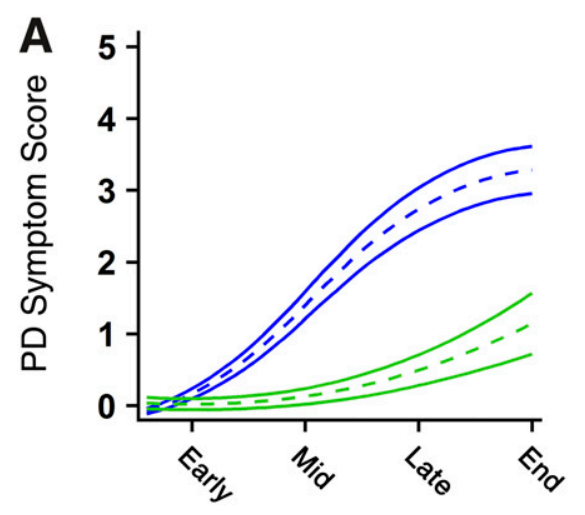

Stage of Pierce's Disease

B

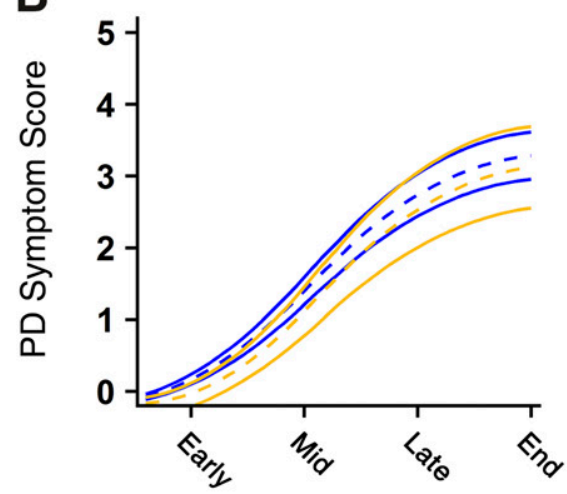

Stage of Pierce's Disease

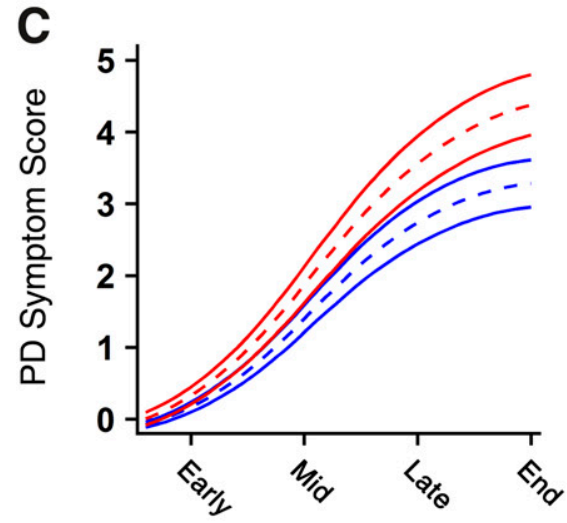

Stage of Pierce's Disease

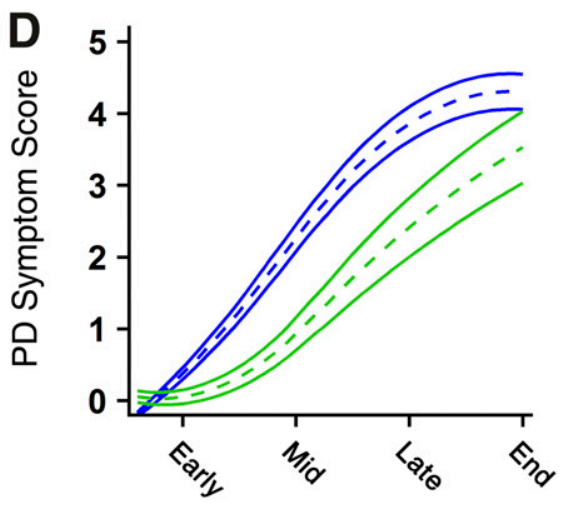

Stage of Pierce's Disease

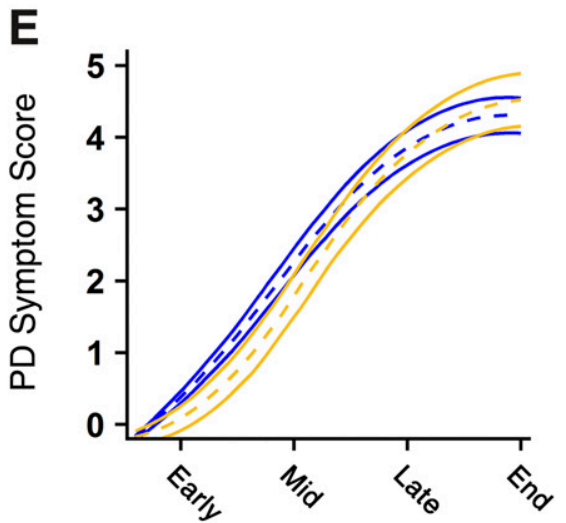

Stage of Pierce's Disease

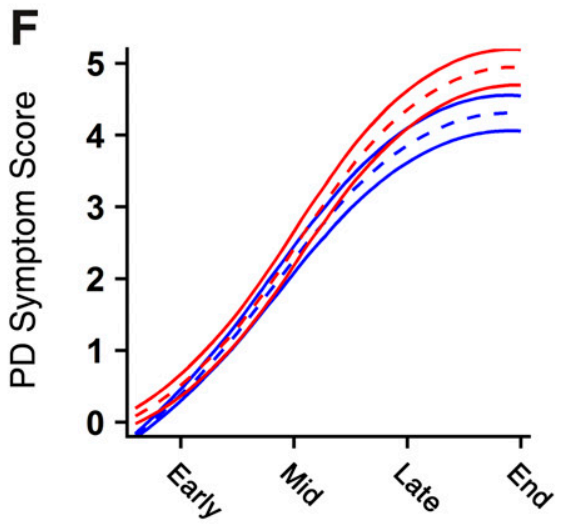

Stage of Pierce's Disease

\section{- Wild type - $\quad$ -}

- $\triangle$ engXCA1

- $\triangle$ engXCA2

Fig. 2. Xylella fastidiosa endoglucanases affect Pierce's disease (PD) severity and the rate of PD symptom development in a cultivar-dependent manner. Estimated mean PD symptom scores generated by the generalized estimating equations model for $\triangle e n g X C A 1$ (yellow), $\triangle e n g X C A 2$ (red), and $\triangle e n g X C A 1 / 2$ (green) were compared with wild type (blue) in cv. Cabernet Sauvignon and in cv. Chardonnay at early, mid, and late stages of PD. A, $\triangle e n g X C A 1 / 2$ induces milder PD symptoms than wild type in Cabernet Sauvignon. B, $\triangle e n g X C A 1$ and wild type induce similar PD symptoms in Cabernet Sauvignon. C, $\triangle e n g X C A 2$ induces more severe PD symptoms than wild type in Cabernet Sauvignon. D, $\Delta e n g X C A 1 / 2$ induces milder PD symptoms than wild type in Chardonnay but to a lesser degree than in Cabernet Sauvignon. E, $\triangle$ engXCAl induces milder symptoms than wild type at the early and mid stages of PD but have symptom severity similar to wild type at the late stage of PD. F, $\triangle$ engXCA2 and wild type induce similar symptoms at the early and mid stages of PD but induce more severe symptoms than wild type at the late stage of PD. Estimated mean PD symptom scores per week are represented by dashed lines, and $95 \%$ confidence intervals are represented by solid lines. 
late-stage $\mathrm{PD}$ in Cabernet Sauvignon vines inoculated with $\Delta e n g X C A 1 / 2$ compared with wild type-inoculated vines, whereas, in Chardonnay there was no difference in the rate of PD symptom development between mid- and late-stage PD (Tables 2 and 3). These data taken together indicate that X. fastidiosa virulence is dependent on EngXCA1 and EngXCA2 in both Chardonnay and Cabernet Sauvignon, but the rate at which PD symptoms develop in the absence of EngXCA1 and EngXCA2 is cultivar dependent.

The $\triangle e n g X C A 1$ single mutant also behaved differently in Chardonnay compared with Cabernet Sauvignon. $\triangle e n g X C A 1-$ inoculated Chardonnay vines only displayed PD symptom scores similar to wild type-inoculated vines at late-stage PD, whereas PD symptom scores in $\triangle e n g X C A 1$-inoculated Cabernet Sauvignon vines were similar to wild type-inoculated vines at mid- and late-stage PD (Fig. 2B and E). Furthermore, the PD symptom progression rate for $\triangle e n g X C A l$-inoculated Chardonnay vines was significantly faster between mid- and latestage PD compared with wild type-inoculated vines (Table 3 ), whereas the PD symptom progression rate for $\triangle e n g X C A 1$ inoculated Cabernet Sauvignon vines was consistently similar to wild type-inoculated vines (Table 2).

$\Delta e n g X C A 2$-inoculated Chardonnay vines had PD symptom scores that were similar to those for wild type-inoculated vines during early- and mid-stage PD, but the $\triangle e n g X C A 2$ mutant elicited significantly higher PD symptom scores than wild-type $X$. fastidiosa during late-stage PD and at the endpoint (Fig. 2F), which differed from its behavior in Cabernet Sauvignon, in which it was hypervirulent at all stages of PD (Fig. 2C). Moreover, PD symptoms in Chardonnay progressed at a similar rate between early- and mid-stage PD in $\triangle e n g X C A 2$ - and wild typeinoculated vines, but progressed faster between mid- and latestage PD in $\triangle$ engXCA2-inoculated vines, whereas in Cabernet Sauvignon PD symptoms progressed faster in $\triangle e n g X C A 2$-inoculated vines at all stages of PD (Tables 2 and 3 ).

In all trials, the disease ratings for phosphate buffered saline (PBS)-inoculated vines (negative controls) for each week were zero. All $P$ values, estimated mean differences, and statistical significance values are summarized in Supplementary Tables $\mathrm{S} 3$ and S4.

\section{EngXCA1 and EngXCA2 are required for complete PM degradation.}

SEM was used to analyze the structural integrity of PMs in both Cabernet Sauvignon and Chardonnay vines inoculated with either wild type or $\triangle e n g X C A 1 / 2$ during late-stage PD. At this stage of PD, the PMs of vines inoculated with wild type were completely dismantled in both cultivars (Fig. 3A and C). In contrast, the PMs of vines inoculated with $\Delta e n g X C A 1 / 2$ were still present and were only partially degraded in both cultivars (Fig. 3B and D). The PMs of the PBS-inoculated control vines for both cultivars remained fully intact (Fig. 1C and D).

\section{Bacterial colonization of the xylem is EngXCA1/EngXCA2-dependent.}

In both Cabernet Sauvignon and Chardonnay, $\Delta e n g X C A 1 / 2$ titers were significantly lower than wild-type titers at the POI and at 20 nodes distal to the POI, indicating that both EngXCA1 and EngXCA2 are concomitantly required to achieve maximal xylem colonization at both points. $\triangle e n g X C A 1$ and $\triangle e n g X C A 2$ single mutant titers at the POI and at 20 nodes distal to the POI were statistically similar to wild-type titers in both cultivars, indicating that deletion of EngXCA1 or EngXCA2 in singlet did not have a quantifiable impact on the ability of $X$. fastidiosa to proliferate at the POI or to move away from the POI during the late phase of infection (Fig. 4). In all trials, bacterial extractions from PBS-inoculated vines (negative controls) did not yield any $X$. fastidiosa colonies. All $P$ values, estimated mean differences, and statistical significance values are summarized in Supplementary Tables S5 and S6.

\section{EngXCA1 has a marginal amount}

of EGase activity compared with EngXCA2.

Initial attempts to measure EGases activity from $X$. fastidiosa itself were unsuccessful; thus, recombinant expression was used to characterize the activities of EngXCA1 and EngXCA2. Previous studies indicated that recombinant EngXCA2 expressed in Escherichia coli possesses robust EGase activity in vitro when using both CMC and xyloglucan as substrates (Pérez-Donoso et al. 2010). A radial diffusion assay was used to determine the zones of CMC hydrolysis for recombinant EngXCA1 using differential staining with Congo red (Fig. 5A). EngXCA2 was included as a positive EGase control, and E. coli harboring the empty pET20b(+) plasmid vector served as a negative control. The area of the zone of hydrolysis for EngXCA1 was determined to be significantly different from that of the pET20b(+) empty vector control $(P=0.02217)$ and from that of EngXCA2 $(P=0.01881)$ (Fig. 5B). Additionally, the area of the zone of hydrolysis for EngXCA2 was determined to be significantly different from the pET20b(+)
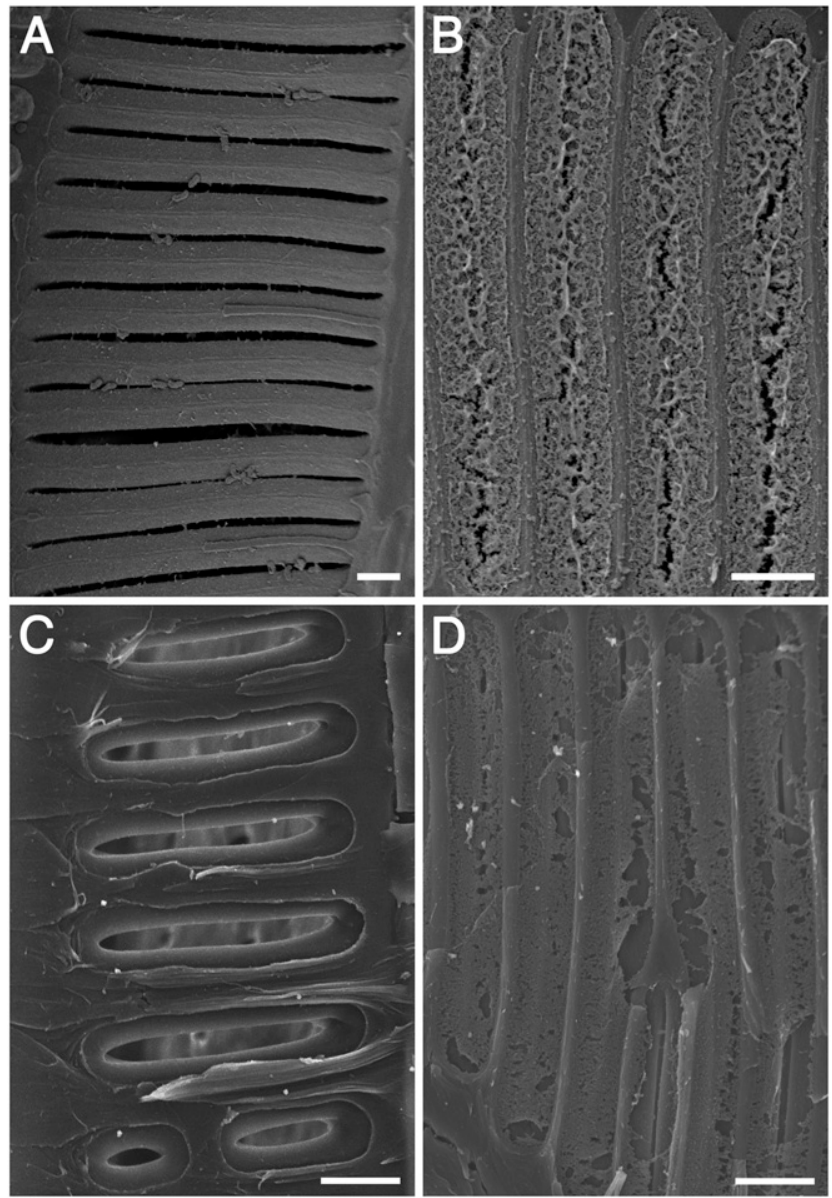

Fig. 3. The $\Delta e n g X C A 1 / 2$ double mutant is impaired in pit membrane (PM) dissolution. The integrity of intervessel PMs in cv. Chardonnay (A and B) and cv. Cabernet Sauvignon (C and D) grapevines inoculated with wild type (A and $\mathrm{C}$ ) and $\triangle e n g X C A 1 / 2$ (B and D) during late-stage infection was analyzed using immunogold-scanning electron microscopy. A and C, All of the intervessel PMs are completely degraded. B and D, Intervessel PMs are still in place but display partial degradation. Scale bar in each panel equals to $5 \mu \mathrm{m}$. 
empty vector control $(P<0.0001)$. Western blotting confirmed the expression of recombinant EngXCA1 and EngXCA2, as well as the absence of expressed protein from the pET20b(+) empty vector control (Supplementary Fig. S3).

\section{DISCUSSION}

Xyloglucans are the most abundant portion of hemicellulose in dicotyledonous plants and can make up as much as $20 \%$ of the dry weight of the primary plant cell wall (Buchanan et al. 2000; Scheller and Ulvskov 2010). Xyloglucans are composed of 1,4-linked $\beta$-D-pyranosyl glucan backbone substituted with 1,6-linked xylose side chains. EGases can digest xyloglucans by cleaving linkages in the glucan backbone, and the $X$. fastidiosa EngXCA2 protein has shown EGase activity when using xyloglucan as a target substrate (Pérez-Donoso et al. 2010). The $X$. fastidiosa EGase mutants tested in this study, particularly the $\Delta e n g X C A 1 / 2$ mutant, affected the rate of PD symptom progression in a cultivar-dependent manner, indicating that enzymatic targets of the EGases are a determining factor in the observed differences in cultivar susceptibility. Because the PM surface is a major interface between pathogen and host, we explored the content of potential
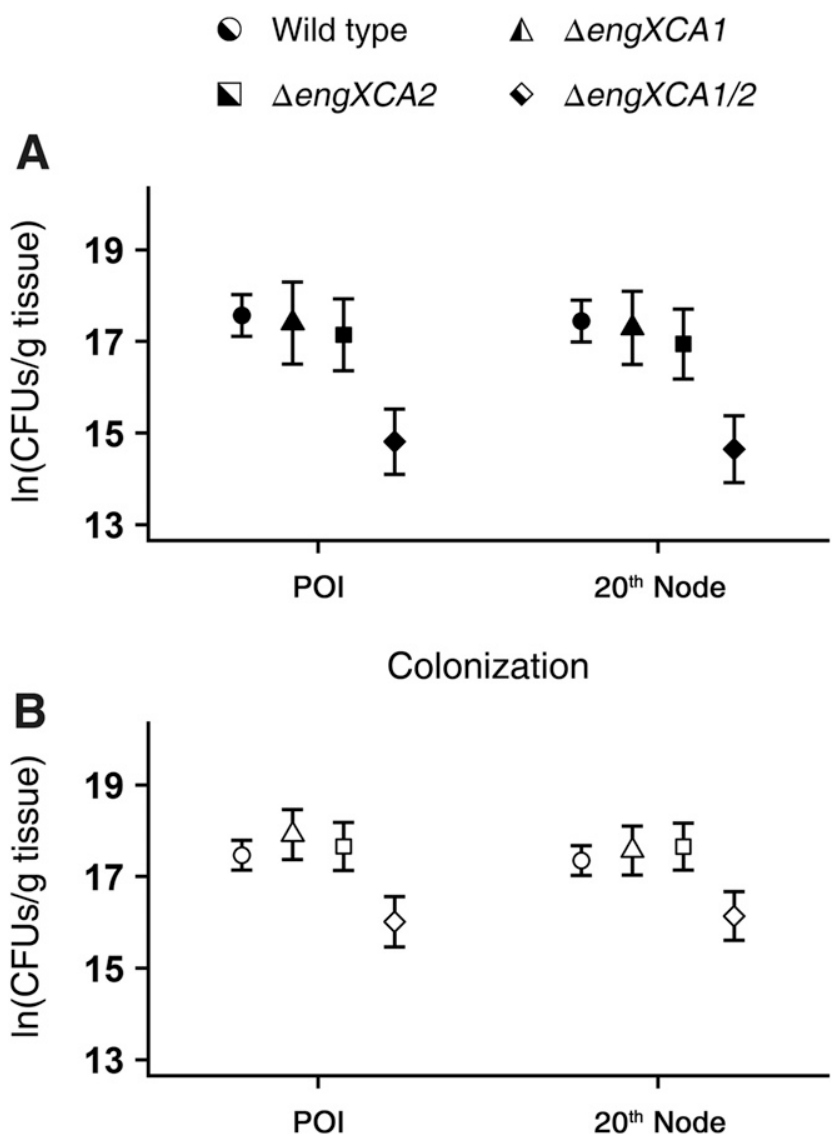

\section{Colonization}

Fig. 4. Xylella fastidiosa colonization is dependent on both EngXCA1 and EngXCA2. Colonization at the point of inoculation (POI) and at 20 nodes distal to the POI in A, cv. Cabernet Sauvignon (black), and B, cv. Chardonnay (white), by $\triangle e n g X C A 1$ (triangle) or $\triangle e n g X C A 2$ (square) is similar to wild type (circle), whereas colonization by $\triangle e n g X C A 1 / 2$ (diamond) at both locations is significantly reduced. Colony forming units were normalized per gram of petiole tissue and transformed using the natural $\log (\ln )$. Statistical comparisons were made using a generalized negative binomial regression model. Error bars represent the standard error of the mean. hemicellulosic target substrates of X. fastidiosa EGases in the xylem PMs of these two cultivars. Indeed, quantitative analyses of the PM surface layer of the highly susceptible Chardonnay cultivar and the more tolerant Cabernet Sauvignon cultivar indicate that Chardonnay PM surfaces contain a higher abundance of fucosylated xyloglucans than the PM surfaces in Cabernet Sauvignon, which contained a relatively low abundance of fucosylated xyloglucans. The rate of PD symptom progression and the overall PD symptom scores were significantly different between Chardonnay and Cabernet Sauvignon and quantitatively confirmed field observations that Chardonnay is significantly more susceptible to PD than is Cabernet Sauvignon.

Interestingly, Sun et al. (2011) determined that the pectin component of Chardonnay PMs is almost exclusively weakly methyl-esterified. PGs are more effective at hydrolyzing pectin with low degrees of methyl esterification, and the effectiveness of PGs in hydrolyzing pectin is inversely proportional to the degree of methyl-esterification (Lionetti et al. 2012). Our data combined with the Sun et al. (2011) study indicate that Chardonnay PMs offer more available target substrates for $X$. fastidiosa CWDEs in the form of weakly methyl-esterified pectin and high quantities of fucosylated xyloglucans that are readily digested by $X$. fastidiosa. It is tempting to speculate that Cabernet Sauvignon PMs contain pectin with high levels of methyl-esterification and that this feature, coupled with low levels of fucosylated xyloglucans, leads to less efficient PM dissolution in Cabernet Sauvignon and could explain why this cultivar is significantly less susceptible to PD compared with Chardonnay. Scanning electron micrographs of PMs in vines inoculated with the $\Delta e n g X C A 1 / 2$ mutant indicate that this mutant does not rupture PMs as readily as its wild-type parent, supporting our hypothesis that EGases target the hemicellulosic

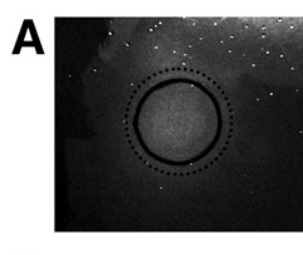

B

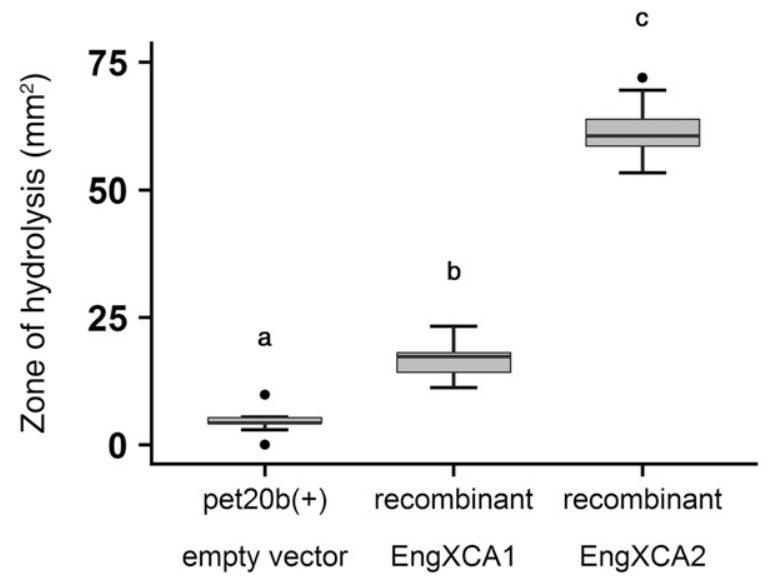

Fig. 5. EngXCA1 has marginal endoglucanase activity. A, A radial diffusion assay shows that recombinant EngXCA1 is able to hydrolyze carboxymethylcellulose (CMC) but much less than the previously characterized Xylella fastidiosa endoglucanase, EngXCA2. B, Recombinant EngXCA1 hydrolyzes significantly more CMC than the empty vector control but significantly less than EngXCA2. Trials consisted of three biological replicates, each consisting of three technical replicates per treatment. Boxplot whiskers represent the minimum and maximum values per treatment, and black dots represent outliers. Letters indicate statistical significance. 
content of PMs. Taken together, these data support previous findings that $\mathrm{PG}$ is the major enzymatic determinant for movement in grapevine xylem and that EGases are accessory enzymes that facilitate PM dissolution (Roper et al. 2007).

The bacterial titer at the POI for each mutant strain was similar to the respective bacterial titer 20 nodes distal to the POI, indicating that none of the EGase mutants were hindered in movement. However, these assays were performed during the late stage of PD, when the vines had a PD symptom score of $\geq 3$ (all leaves have some scorching with a few matchstick petioles), which was at the end of the linear portion of the PD symptom curve. It is possible that movement could be delayed for certain EGase mutants during the earlier phases of infection and that the timing of the colonization assay did not capture this delay. Several attempts to isolate $X$. fastidiosa from grapevines at earlier time points were not successful. Our own previous work (Clifford et al. 2013; Wang et al. 2017) and work performed by other research groups indicates that $X$. fastidiosa cannot be consistently quantified in grapevines with PD symptom scores $<3$ (Deyett et al. 2019).

Soluble carbohydrates in xylem sap are in relatively low abundance, and the carbohydrate composition of xylem sap fluctuates over the course of the growing season (Roper 2006). Thus, soluble carbohydrates are likely to be an inconsistent source of carbon for a microorganism living in the xylem (Andersen and Brodbeck 1989; Hardy and Possingham 1969; Loescher et al. 1990). The carbohydrate content of PMs may serve as a reliable and sustainable source of carbon that $X$. fastidiosa utilizes to augment any carbon obtained from xylem sap. Neither $\triangle e n g X C A 1$ nor $\triangle e n g X C A 2$ were impaired in population growth compared with wild type in both cultivars, but proliferation of the $\Delta e n g X C A 1 / 2$ mutant was significantly impaired within the xylem, supporting the hypothesis that these two EGases play a collective role in harvesting carbon in the xylem environment. However, despite this impairment, the $\triangle e n g X C A 1 / 2$ mutant population did increase, indicating that the PG may also have a role in carbon acquisition. It is possible that the different roles of these EGases allow them to act synergistically to degrade PMs and harvest carbon. However, our data suggest that these EGases act in a redundant manner, in which one can compensate for the loss of the other.

In accordance with this carbon acquisition hypothesis, we expected that there would be a significant difference in bacterial titer in Chardonnay and Cabernet Sauvignon, with the less susceptible variety harboring less $X$. fastidiosa. However, both cultivars supported similar populations of bacteria at the POI and at 20 nodes distal to the POI. As mentioned above, this result is likely due to the inability to quantify $X$. fastidiosa titer in grapevine tissue during the early phases of $X$. fastidiosa infection when bacterial titer is below the threshold of reliable detection. Thus, we speculate that the $X$. fastidiosa titer may be lower in the less susceptible Cabernet Sauvignon cultivar at earlier time points.

EngXCA1 is predicted to be a chimeric protein comprised of an EGase domain and an expansin domain (Cosgrove 2017). There are only a few examples of bacterial expansins, and they are almost exclusively found in bacteria that have a xylemdwelling component of their lifestyle and have varying roles in virulence (Cosgrove 2017; Nikolaidis et al. 2014). Deletion of one expansin in Clavibacter michiganensis subsp. michiganensis resulted in a hypervirulent phenotype in tomato, whereas deletion of one expansin in Ralstonia solanacearum resulted in a hypovirulent phenotype for root inoculations (Tancos et al. 2018). EngXCA1 digested a $\beta$-1,4 linked glucan backbone (CMC), indicating that it possesses EGases activity. However, the zone of hydrolysis of the CMC substrate was significantly smaller relative to a lower concentration of EngXCA2, indicating that EngXCA1 is a less potent EGase than EngXCA2 in vitro. Additionally, the loss of only EngXCA1 had a small, but significant, impact on $X$. fastidiosa virulence in the early stages of infection in Chardonnay. This leads us to speculate that the primary role of EngXCA1 is to function as an expansin rather than an EGase in vivo. Expansins disrupt the bonds between hemicellulosic xyloglucans and the hydrophobic regions of cellulose microfibrils, allowing relaxation of the cell wall and subsequent extension (Cosgrove 2018). EngXCA1 could aid the PM degradation process by acting as an expansin and disrupting the bonds between cellulose and xyloglucans, thereby providing other CWDEs, such as EngXCA2 and PG, with easier access to target substrates. This effect would be most evident in highly susceptible varieties (e.g., Chardonnay) that contain high amounts of fucosylated xyloglucans in PMs. Deletion of EngXCA1 had little effect on PD severity in Cabernet Sauvignon, in which the PMs have a lower abundance of fucosylated xyloglucans relative to Chardonnay, supporting the hypothesis that the amount of crosslinking glycans mediates PM integrity.

In an ex vivo study in grapevine stem explants, purified recombinant $X$. fastidiosa EngXCA2 was required for PM dissolution in collaboration with a purified PG. Thus, it was surprising that the $X$. fastidiosa $\triangle$ engXCA2 mutant was hypervirulent and had a faster PD symptom progression rate in both Cabernet Sauvignon and Chardonnay. Hypervirulent phenotypes have been documented for mutant strains of $X$. fastidiosa that do not aggregate or form biofilms and are locked in the planktonic, exploratory state in the xylem (Burbank and Stenger 2017; Chatterjee et al. 2008b; Gouran et al. 2016; Guilhabert and Kirkpatrick 2005; Newman et al. 2004). Interestingly, the $\triangle e n g X C A 2$ mutant had a mucoid colony morphotype on solid medium compared with wild-type $X$. fastidiosa cells that have a comparatively drier colony phenotype. Furthermore, the $\triangle e n g X C A 2$ mutant did not aggregate in liquid cultures (data not shown). Overproduction or deregulation of exopolysaccharides (EPS) can have an adverse effect on the ability of bacteria to attach to surfaces and selfaggregate, both of which are hallmarks of the regimented developmental processes related to biofilm formation (Dertli et al. 2015; Koutsoudis et al. 2006; Rendueles et al. 2013). Therefore, it is likely that excessive EPS accumulation in the $\triangle e n g X C A 2$ mutant disrupts cell-to-cell adhesion and, subsequently, early biofilm developmental processes that are known to be an important factor in attenuating $X$. fastidiosa virulence early in the xylem colonization process (Guilhabert and Kirkpatrick 2005; Rapicavoli et al. 2018), which leads to the observed hypervirulent phenotype for the $\triangle e n g X C A 2$ mutant. The $X$. fastidiosa EPS molecule is predicted to be composed of a $\beta-1,4$ linked glucan backbone, which could be a substrate of EngXCA2. Our data indicate that EngXCA2 could play a dual role in the biology of $X$. fastidiosa, one of which is that of a traditional plant CWDE that targets primary plant cell walls and the other in facilitating the turnover of EPS. Further studies on the role of EngXCA2 in EPS processing and biofilm development are warranted.

Our findings indicate PM composition is an important component of the plant-microbe interaction between cultivated grapevines and $X$. fastidiosa. In highly susceptible cultivars, the abundance of readily accessible carbohydrates in PMs that are compatible with $X$. fastidiosa CWDEs facilitates a greater PD symptom progression rate. In contrast, PD symptom progression is slower in more tolerant varieties that have lower abundances of substrates that are compatible with $X$. fastidiosa CWDEs. Little is known about PM composition in the many plant hosts in which $X$. fastidiosa resides as a commensal 
bacterium without causing disease (Freitag 1951). Our data suggest that the carbohydrate composition of PMs in tolerant grapevines may be less compatible with $X$. fastidiosa CWDEs than the PM carbohydrate composition found in susceptible hosts. Furthermore, PM carbohydrate composition may be a factor in plant-microbe interactions that determines where bacteria fall on the symbiosis spectrum of commensalism or parasitism.

\section{MATERIALS AND METHODS}

\section{Bacterial strains.}

All bacterial strains, plasmids, and primers used in this study are listed in Table 4.

\section{Media and bacterial growth conditions.}

$X$. fastidiosa strains were grown at $28^{\circ} \mathrm{C}$ in PD3 broth and solid medium (Davis et al. 1981). E. coli strains were grown at $37^{\circ} \mathrm{C}$ in Luria-Bertani (LB) medium. Selection of $X$. fastidiosa transformants was performed on PD3 with kanamycin or gentamicin $(5 \mu \mathrm{g} / \mathrm{ml})$, and subculturing of transformants was performed on PD3 with kanamycin $(30 \mu \mathrm{g} / \mathrm{ml})$ or gentamicin $(10 \mu \mathrm{g} / \mathrm{ml})$, when appropriate. For selection of $E$. coli transformants, kanamycin $(30 \mu \mathrm{g} / \mathrm{ml})$ or gentamicin $(10 \mu \mathrm{g} / \mathrm{ml})$ was added.

\section{Construction of the $\triangle e n g X C A 1, \triangle e n g X C A 2$, and $\triangle e n g X C A 1 / 2$ mutants.}

Overlap extension PCR was used to combine $5^{\prime}$ and $3^{\prime}$ flanking regions adjacent to the target gene (engXCAl or engXCA2) with an antibiotic resistance gene to create a deletion construct. Homologous recombination between flanking regions of the deletion construct and the same regions within the $X$. fastidiosa chromosome facilitated complete removal of the target gene and subsequent insertion of the antibiotic resistance gene. The $5^{\prime}$ and $3^{\prime}$ flanking regions adjacent to engXCAl were amplified from the $X$. fastidiosa chromosome via PCR using primer pairs engXCA1_LF_fwd and engXCA1_LF-rev and engXCA1_RF_fwd and engXCA1_RF_rev, respectively. The kanamycin resistance gene was amplified from pCR2.1 TOPO (Invitrogen) using primers engXCA1_kan_fwd and engXCA1_kan_rev. The $5^{\prime}$ and $3^{\prime}$ flanking regions adjacent to engXCA2 were amplified from the $X$. fastidiosa chromosome via PCR using primer pairs engXCA2_LF_fwd and engXCA2_LF-rev and engXCA2_RF_fwd and engXCA2_RF_rev, respectively. The gentamicin resistance gene was amplified from the pBBR1-MCS5 plasmid (Kovach et al. 1995) using primers engXCA2_gent_fwd and engXCA2_gent_rev. Individual fragments for each deletion construct were amplified using Ex Taq DNA polymerase (Takara) and 30 PCR cycles: denaturation at $95^{\circ} \mathrm{C}$ for $1 \mathrm{~min}$; primer annealing at $60^{\circ} \mathrm{C}$ for

Table 4. Strains, plasmids, and primer sequences used in this study

\begin{tabular}{|c|c|c|}
\hline Strains, plasmids, and primers & Relevant characteristics or primer sequence $^{a}$ & Source \\
\hline \multicolumn{3}{|l|}{ Strain } \\
\hline Escherichia coli TOP10 & $\begin{array}{l}\text { F- } m c r \mathrm{~A} \Delta(m r r-h s d \mathrm{RMS}-m c r \mathrm{BC}) \text { } \Phi 80 \text { lacZ } \Delta \mathrm{M} 15 \Delta \text { lacX74 } \\
\text { recA1 araD139 } \Delta(\text { araleu }) 7697 \text { galU galK rpsL (StrR) } \\
\text { endA1 nupG }\end{array}$ & Invitrogen \\
\hline Xylella fastidiosa Temecula 1 & & Temecula, CA, U.S.A. \\
\hline Xylella fastidiosa $\triangle$ engXCAI & engXCA1 deletion in Temecula 1 background & This study \\
\hline Xylella fastidiosa $\triangle$ engXCA2 & engXCA2 deletion in Temecula 1 background & This study \\
\hline Xylella fastidiosa $\triangle$ engXCA1/2 & engXCA1 and engXCA2 deletions in Temecula 1 background & This study \\
\hline \multicolumn{3}{|l|}{ Plasmid } \\
\hline pCR8/GW/TOPO & pUC19 derivative, spectinomycin-resistant & Invitrogen \\
\hline pCR2.1 TOPO & Kanamycin-resistant & Invitrogen \\
\hline pBBR1-MCS5 & Gentamicin-resistant & Kovach et al. 1995 \\
\hline BI1 & pCR8/GW/TOPO with $\triangle e n g X C A 1$ deletion construct & This study \\
\hline $\mathrm{BI} 2$ & pCR8/GW/TOPO with $\triangle e n g X C A 2$ deletion construct & This study \\
\hline $\mathrm{BI} 3$ & pET $20 \mathrm{~b}(+)$ protein expression vector with engXCA1 gene & This study \\
\hline MCR7 & pET $20 \mathrm{~b}(+)$ protein expression vector with engXCA2 gene & $\begin{array}{l}\text { Pérez-Donoso } \\
\text { et al. } 2010\end{array}$ \\
\hline \multicolumn{3}{|l|}{ Primer } \\
\hline engXCA1_LF_fwd & CGATCCGCCACGCTTCAGTATTGCC & This study \\
\hline engXCA1_LF_rev & GGGCTTCCCAACCTTGACCGTGACT & This study \\
\hline engXCA1_kan_fwd & AGTCACGGTCAAGGTTGGGAAGCCC & This study \\
\hline engXCA1_kan_rev & GCAACATCCGGTTGCTACTTTCACCAG & This study \\
\hline engXCA1_RF_fwd & CTGGTGAAAGTAGCAACCGGATGTTGC & This study \\
\hline engXCA1_RF_rev & CCACACTCGCAGTGGCGCTTATTGG & This study \\
\hline engXCA2_LF_fwd & TGCGTCCATAGACGCTTGCCATC & This study \\
\hline engXCA2_LF_rev & CCACGGTGTGCGTCTAAGTATCCTTAATAGG & This study \\
\hline engXCA2_gent_fwd & CCTATTAAGGATACTTAGACGCACACCGTGG & This study \\
\hline engXCA2_gent_rev & GGAATAGAAAATGCACTTTAGGTGGCGGTACTTG & This study \\
\hline engXCA2_RF_fwd & CAAGTACCGCCACCTAAAGTGCATTTTCTATTCC & This study \\
\hline engXCA2_RF_rev & GTTCCGAGACCGAGAATACCGATGATGAG & This study \\
\hline GW1 & GTTGCAACAAATTGATGAGCAATGC & Invitrogen \\
\hline GW2 & TAATTGCTCATCAATTTGTTGCAAC & Invitrogen \\
\hline engXCA1_XfgenDNA_For_seq & CCTCAGGCGATACAGGCTAATCAGC & This study \\
\hline engXCA1_XfgenDNA_Rev_seq & CGCTCAGGTCATTCGTGATACACC & This study \\
\hline engXCA1mut_Kan_For_seq & ATCGCCTTCTTGACGAGTTCTTCTG & This study \\
\hline engXCA1mut_Kan_Rev_seq & CTGCGTGCAATCCATCTTGTTCAATC & This study \\
\hline Xf_engXCA2_PCR_fwd & CCGGTTTCAAAGTCGGGATC & This study \\
\hline Xf_engXCA2_PCR_rev & ATGTGCGAACCCAGTTTTCC & This study \\
\hline Xf_engXCA2seq_9 $\overline{2}$ outLF & CCTGCCCCTGAGTCAAAGAG & This study \\
\hline Xf_engXCA2seq_71intLF & CCCTAACGGCGTTTGAATCAC & This study \\
\hline Gent_seq_fwd & GACGCACACCGTGGAAACGGATGAAG & This study \\
\hline Xf_engXCA2seq_33intRF & CGGAGTGGTAACGATGGCAT & This study \\
\hline
\end{tabular}

${ }^{a}$ Primer sequences are presented $5^{\prime}$ to $3^{\prime}$. 
$1 \mathrm{~min}$; extension at $72^{\circ} \mathrm{C}$ for $2 \mathrm{~min}$. The three fragments for each deletion construct were assembled by overlap extension PCR, and the resulting products were cloned into pCR8/GW/TOPO (Invitrogen) following the manufacturers' instructions to create plasmids pBI1 and $\mathrm{pBI} 2$. The $\triangle$ engXCA1 construct was verified by sequencing using primers GW1 and GW2 (Invitrogen) and engXCA1_kan_fwd and engXCA1_ kan_rev. The $\triangle e n g X C A 2$ construct was verified by sequencing using primers GW1 and GW2 (Invitrogen) and engXCA2 gent_fwd and engXCA2_gent_rev. Either pBI1 or pBI2 was transformed into $X$. fastidiosa by electroporation. Electrocompetent $X$. fastidiosa cells were prepared according to Matsumoto et al. (2009), and $200 \mathrm{ng}$ of pBI1 or pBI2 and $1 \mu \mathrm{l}$ of TypeOne restriction inhibitor (Epicentre) were electroporated $(3.0 \mathrm{kV}, 300 \Omega, 25 \mu \mathrm{F}$ ) into $X$. fastidiosa using a 0.2 -cm cuvette (Bio-Rad) and the GenePulser X-cell (Bio-Rad). Positive transformants were validated via subculturing onto PD3 agar containing the appropriate antibiotics. Genomic DNA from $X$. fastidiosa $\triangle e n g X C A 1$ and $X$. fastidiosa $\triangle e n g X C A 2$ positive transformants was extracted using the DNeasy blood and tissue kit (Qiagen). $\triangle e n g X C A 1$ was verified by sequencing using primers engXCA1_XfgenDNA_For_seq, engXCA1_XfgenDNA_ Rev_seq, engXCA1mut_Kan_For_seq, and engXCA1mut_Kan_ Rev_seq. $\triangle e n g X C A 2$ was verified by sequencing using primers Xf_engXCA2_PCR_fwd, Xf_engXCA2_PCR_rev, Xf_engXCA2seq_92outLF, Xf_engXCA2seq_71intLF, Gent_seq_fwd, and Xf_ engXCA2seq_33intRF. The $X$. fastidiosa $\Delta$ engXCA1/2 double mutant strain was created by transforming electrocompetent $\triangle e n g X C A 1$ cells with $200 \mathrm{ng}$ of the pBI 2 plasmid and $1 \mu \mathrm{l}$ of TypeOne restriction inhibitor (Epicentre). Positive transformants were obtained and screened as described above. All relevant primers can be found in Table 4. Complementation tools are limited for $X$. fastidiosa, and repeated attempts to obtain transformants for complementation of the EGase mutants were unsuccessful.

\section{Recombinant EngXCA1 and EngXCA2 protein expression.}

The engXCA1 gene was inserted into the $\mathrm{pET} 20 \mathrm{~b}(+)$ protein expression vector to create $\mathrm{pBI} 3$ (Genscript USA Inc.). The gene was inserted between the $S a c \mathrm{I}$ and XhoI restriction sites, and the codon sequence was aligned to include a histidine (His) tag and the periplasmic localization signal peptide. The pBI3 plasmid was used to transform E. coli BL21 DE3. Single colonies of $E$. coli harboring either pBI3, pMCR7 (Pérez-Donoso et al. 2010), or empty vector (pET20b(+)) were grown in $5 \mathrm{ml}$ of liquid LB media containing ampicillin $(100 \mu \mathrm{g} / \mathrm{ml})$ at $37^{\circ} \mathrm{C}$ while shaking at $200 \mathrm{rpm}$ overnight. Each overnight culture (4 ml) was added to $400 \mathrm{ml}$ of liquid LB media containing ampicillin $(100 \mu \mathrm{g} / \mathrm{ml})$, and each culture was incubated at $37^{\circ} \mathrm{C}$ while shaking at $200 \mathrm{rpm}$ until each had an optical density $\left(\mathrm{OD}_{600}\right)=0.5$. The cultures were centrifuged at 5,000 rpm for $10 \mathrm{~min}$, the supernatant was discarded, and cell pellets were resuspended in $400 \mathrm{ml}$ of fresh LB media containing ampicillin $(100 \mu \mathrm{g} / \mathrm{ml})$ and $0.6 \mathrm{mM}$ isopropyl $\beta$-D-1-thiogalactopyranoside to induce protein production. The cultures were incubated at $4{ }^{\circ} \mathrm{C}$ while shaking at $200 \mathrm{rpm}$ overnight. After protein induction, the cultures were split in half to assess both protein expression via Western blotting and EGase activity.

Cell cultures $(200 \mathrm{ml})$ expressing recombinant EngXCA1, recombinant EngXCA2, or the pET20b(+) empty vector were centrifuged at 5,000 rpm for $10 \mathrm{~min}$. Cell pellets were freezethawed twice at $-80^{\circ} \mathrm{C}$, then lysed using the B-PER Complete lysis reagent (Thermo Scientific), following the manufacturers' instructions. A protease inhibitor was added during cell lysis to prevent protein degradation. Lysed samples were mixed 1:1 with $2 \times$ Laemmli buffer (Bio-Rad), boiled for $5 \mathrm{~min}$, and subjected to sodium dodecyl sulfate-polyacrylamide gel electrophoresis using a $10 \%$ polyacrylamide gel. The protein was then transferred to a $0.45-\mu \mathrm{m}$ nitrocellulose membrane overnight. The membrane was blocked with $5 \%$ nonfat milk and then probed with an $\alpha$-His tag primary monoclonal antibody (Thermo Scientific) followed by a goat $\alpha$-mouse secondary polyclonal antibody conjugated with alkaline phosphatase (Thermo Scientific). The blot was developed using the AP development kit (Bio-Rad), following the manufacturers' instructions.

\section{EGase activity assay.}

Cell cultures $(200 \mathrm{ml})$ expressing recombinant EngXCA1, recombinant EngXCA2, or the pET20b(+) empty vector were centrifuged at 5,000 rpm for $10 \mathrm{~min}$, and cell pellets were each resuspended in $1 \mathrm{ml}$ of $1 \times \mathrm{PBS}$ ( $\mathrm{pH} 7.4)$. Each cell resuspension $(50 \mu \mathrm{l})$ was placed onto the center of a respective plate containing $1 \%$ agarose (medium EEO, Fisher Scientific) and $0.2 \%$ CMC (Sigma-Aldrich) in phosphate buffer ( $\mathrm{pH}$ 6.0) and incubated at $37^{\circ} \mathrm{C}$ for $48 \mathrm{~h}$. After incubation, the perimeter of each cell droplet was marked, the diameter was measured using calipers, and then the cells were removed with copious amounts of water. Each plate was flooded with $0.1 \%$ Congo red dye (Sigma-Aldrich), followed by flooding with $1 \mathrm{M}$ sodium chloride twice, and then flooding with 5\% acetic acid (Carder 1986). The perimeter of each zone of hydrolysis was marked, and the diameter was measured using calipers. The area of each zone of hydrolysis was calculated and normalized by subtracting the area of the associated cell droplet. The assay was performed with three biological replicates containing three technical replicates of each treatment. Statistical significance between treatments was determined using the Kruskal-Wallis rank sum test for nonparametric data. Pairwise comparisons were made using Dunn's multiple comparison test, and $P$ values were adjusted using the Benjamini-Hochberg false discovery rate method.

\section{In planta virulence assays.}

Vitis vinifera cv. Cabernet Sauvignon and cv. Chardonnay were propagated from cuttings (generously provided by Foundation Plant Services (UC Davis)). Vines were mechanically inoculated following the methodology outlined by Purcell and Saunders (1999). Briefly, a 20- $\mu$ l drop with $10^{8}$ $\mathrm{CFU} / \mathrm{ml}$ of $X$. fastidiosa inoculum was placed on the stem between the third and fourth nodes. The stem was pierced through the drop using a 20-gauge needle, and the drop was drawn into the xylem. Grapevines were inoculated with wild type, $\Delta e n g X C A 1, \Delta e n g X C A 2$, or $\triangle e n g X C A 1 / 2 X$. fastidiosa strains. Grapevines inoculated with $1 \times$ PBS served as negative controls. Within trials, each strain was inoculated into 10 vines and the experiment was repeated three times for a total of 30 replicates per strain (or $1 \times$ PBS) inoculation. All trials were randomized in the greenhouse, and vines were given a weekly PD symptom score based on the established rating scale from 0 to 5 as described in Guilhabert and Kirkpatrick (2005), where $0=\mathrm{a}$ healthy vine, $1=$ one or two leaves with scorching at the margins, 2 = two or three leaves with more developed scorching, 3 = all leaves with some scorching and a few matchstick petioles, $4=$ all leaves with heavy scorching and many matchstick petioles, and $5=\mathrm{a}$ dead or dying vine. Each trial compared PD symptom scores over a 20 -week period in Cabernet Sauvignon and Chardonnay grapevines inoculated with either wild type or one mutant strain. Each trial was completed twice over a 2-year period, for a total of six pathogenicity assays: two comparing wild type and $\triangle e n g X C A 1$, two comparing wild type and $\triangle e n g X C A 2$, and two comparing wild type and $\triangle e n g X C A 1 / 2$. Because wild type was present in every trial, data for wild type-inoculated vines was combined for each 
vine type and used as a reference to make comparisons to data from vines inoculated with each of the mutants across multiple trials and years. The mean PD symptom score per week was calculated, and comparisons between wild type and each of the mutants were made at 5 WPI (early-stage PD), 10 WPI (midstage PD), 15 WPI (late-stage PD), and 20 WPI (endpoint). The rate of $\mathrm{PD}$ symptom progression was assessed within the linear portion of the disease curve (5 to $15 \mathrm{WPI}$ ) by calculating the slopes between early- and mid-stage PD (5 to $10 \mathrm{WPI}$ ) and midand late-stage PD (10 to $15 \mathrm{WPI}$ ).

\section{Local and distal xylem colonization assays.}

Grapevines were inoculated as described above. To determine the contribution of EGases in local xylem colonization, wild-type, $\triangle e n g X C A 1$, $\triangle e n g X C A 2$, and $\triangle e n g X C A 1 / 2$ populations per gram of tissue were quantified by isolating $X$. fastidiosa from the first intact petiole closest to the POI. Additionally, isolations were performed on petioles from the twentieth node distal to the POI to determine whether the EGases (singly or in tandem) had an impact on movement. Petioles were collected from every vine in each of the six trials after the late-stage infection time point, surface-sterilized $(30 \mathrm{~s}$ in $70 \%$ ethanol, $30 \mathrm{~s}$ in $10 \%$ bleach, and twice for $1 \mathrm{~min}$ in sterile deionized water), and ground in $2 \mathrm{ml}$ of sterile $1 \times$ PBS. The resulting suspension was diluted, and the dilution series was plated on solid PD3 medium according to standard methods (Roper et al. 2007). X. fastidiosa titers were normalized by dividing colony counts (colony forming units) by the weight of the corresponding petiole (colony forming units per gram of tissue). The titers for wild type-inoculated vines from all trials were combined for each vine type and used as a reference, and wild-type titers were compared with the titers of each mutant.

\section{Integrity and polysaccharide composition of intervessel PMs.}

An immunogold SEM technique was used to reveal intervessel PM structure and immuno-localized fucosylated xyloglucans on the PMs of Chardonnay and Cabernet Sauvignon vines at the late-stage time point of PD symptom development. Details of the technique can be found in Sun et al. (2017). In brief, the third internode above the inoculated internode of each vine was fixed in $4 \%$ paraformaldehyde in PEM buffer $(50 \mathrm{mM}$ PIPES, $5 \mathrm{mM}$ EGTA, $5 \mathrm{mM} \mathrm{MgSO}$, $\mathrm{pH}$ 6.9) for at least $24 \mathrm{~h}$. Each internode was then trimmed into $3 \mathrm{~mm}$ wide $\times 5 \mathrm{~mm}$ long $\times 1 \mathrm{~mm}$ thick longitudinal segments, exposing either a radial or tangential surface of the secondary xylem. Trimmed specimens were washed twice with $50 \mathrm{mM}$ PIPES and once with $0.2 \mathrm{M}$ PBS with $3 \%$ nonfat milk powder (MP/PBS, pH 7.4) for $30 \mathrm{~min}$ for each wash. Subsequently, specimens were divided into three groups, with one as the immune-localization treatment and the other two as controls. A monoclonal antibody (mAb, CCRC$\mathrm{M} 1)$ and a corresponding secondary Ab (gold-conjugated goat antimouse $\mathrm{IgG}$ ) were used to detect fucosylated xyloglucans on intervessel PMs. Specimens for each treatment were incubated at $4{ }^{\circ} \mathrm{C}$ overnight in a threefold dilution of the original $\mathrm{mAb}$ mouse hybridoma supernatant in $3 \% \mathrm{MP} / \mathrm{PBS}$. After three PBS washes of $10 \mathrm{~min}$ each, specimens were incubated at room temperature (RT) for $1 \mathrm{~h}$ with a 50 -fold dilution in $3 \% \mathrm{MP} / \mathrm{PBS}$ of the original colloidal gold-conjugated goat antimouse IgG. Incubation was followed by three 10-min washes of deionized water and one 15-min silver enhancement treatment. Silverenhanced specimens were washed twice in deionized water (10 min each), and dehydrated via an ethanol series. Dehydrated specimens were critical-point dried, sputter-coated with gold-palladium, and then examined at an accelerating voltage of $5 \mathrm{kV}$ or $8 \mathrm{kV}$ under a Hitachi 3400N SEM in the University of Wisconsin Stevens Point Biology Department. The other two sets of specimens used for controls were processed in the same way described above, except that the mAb or secondary $\mathrm{Ab}$ incubation step was replaced with the $3 \% \mathrm{MP} / \mathrm{PBS}$ incubation within either of the two sets of specimens, respectively. Silverenhanced gold particles appear as bright particles and indicate the presence, quantity, and distribution of fucosylated xyloglucans on intervessel PMs of the polysaccharide group. Specimens of either treatment or controls also were examined with SEM to reveal structural features of intervessel PMs.

\section{Statistical analyses.}

Longitudinal disease ratings are discrete, non-Gaussian, observations. Therefore, a GEE model was used for this analysis (Liang and Zeger 1986). The time trend was captured using a quadratic spline with knots at 5 weeks and 10 weeks. A GEE model with a quadratic spline time trend provided a robust approach to the data analysis. A full model with year, cultivar, strain, and time as main effects, cultivar $\times$ strain, cultivar $\times$ time, and strain $\times$ time as two-factor interactions, and cultivar $\times$ strain $\times$ time as a three-factor interaction was fit to the complete data set of disease ratings. The three-factor interaction was significant in the model, and therefore, least squares means (LSM), standard errors, and $95 \%$ confidence intervals for the mean disease rating for each combination of cultivar, strain, and time were obtained.

For each strain, contrasts between cultivars at each time point were carried out using two-sided asymptotic Z-tests based on the LSM. Within a cultivar, the three mutants were contrasted with wild type at each time point using a two-sided asymptotic Z-test. The LSM were used to estimate rates of PD symptom progression as the slopes between times 5 and 10 weeks, and between times 10 and 15 weeks. The two slopes were similarly contrasted between cultivar and within cultivar using two-sided asymptotic Z-tests.

Bacterial titer is an integer-valued count that was highly variable and contained several zeros. Therefore, a negative binomial generalized linear model (GLM) was used to analyze bacterial titer (McCullagh and Nelder 1989). Between-cultivar comparisons utilized a negative binomial GLM for each combination of strain and colonization location, and which coded cultivar using two dummy variables. Cultivars were compared using a two-sided asymptotic Wald test. Within-cultivar comparisons utilized a negative binomial GLM for each colonization location, and which coded strain with four dummy variables. Because mutant counts were expected to be lower than wild-type counts, contrasts of each mutant with wild type were carried out with lower one-sided asymptotic Wald tests.

All analyses were performed in SAS 9.4 (SAS Institute) using the GENMOD procedure.

\section{ACKNOWLEDGMENTS}

Grapevine cuttings used in this work were provided by Foundation Plant Services, University of California, Davis. The authors also thank P. Rolshausen for thoughtful discussions on cultivar susceptibility to vascular diseases.

\section{LITERATURE CITED}

Almeida, R. P. P., and Nunney, L. 2015. How do plant diseases caused by Xylella fastidiosa emerge? Plant Dis. 99:1457-1467.

Andersen, P. C., and Brodbeck, B. V. 1989. Diurnal and temporal changes in the chemical profile of xylem exudate from Vitis rotundifolia. Physiol. Plant. 75:63-70.

Barras, F., van Gijsegem, F., and Chatterjee, A. K. 1994. Extracellular enzymes and pathogenesis of soft-rot Erwinia. Ann. Rev. Phytopathol. 32:201-234.

Bateman, D. F. 1976. Plant cell wall hydrolysis by pathogens. Pages 79-103 in: Biochemical Aspects of Plant-Parasite Relationships. J. Friend and D. R. Threlfall, eds. Academic Press, London. 
Brett, C. T., and Waldron, K. W. 1996. Physiology and Biochemistry of Plant Cell Walls. Springer Science \& Business Media, Heidelberg, Germany.

Buchanan, B. B., Gruissem, W., and Jones, R. L. 2000. The cell wall. Pages 52-100 in: Biochemistry and Molecular Biology of Plants. American Society of Plant Physiologists, Rockville, MD.

Burbank, L. P., and Stenger, D. C. 2017. The DinJ/RelE toxin-antitoxin system suppresses bacterial proliferation and virulence of Xylella fastidiosa in grapevine. Phytopathology 107:388-394.

Carder, J. H. 1986. Detection and quantitation of cellulase by Congo red staining of substrates in a cup-plate diffusion assay. Anal. Biochem. 153: 75-79.

Chang, C. J., Garnier, M., Zreik, L., Rossetti, V., and Bové, J. M. 1993. Culture and serological detection of the xylem-limited bacterium causing citrus variegated chlorosis and its identification as a strain of Xylella fastidiosa. Curr. Microbiol. 27:137-142.

Chatterjee, S., Almeida, R. P. P., and Lindow, S. 2008a. Living in two worlds: The plant and insect lifestyles of Xylella fastidiosa. Annu. Rev. Phytopathol. 46:243-271.

Chatterjee, S., Wistrom, C., and Lindow, S. E. 2008b. A cell-cell signaling sensor is required for virulence and insect transmission of Xylella fastidiosa. Proc. Natl. Acad. Sci. U.S.A. 105:2670-2675.

Choat, B., Jansen, S., Zwieniecki, M. A., Smets, E., and Holbrook, N. M. 2004. Changes in pit membrane porosity due to deflection and stretching: The role of vestured pits. J. Exp. Bot. 55:1569-1575.

Clifford, J. C., Rapicavoli, J. N., and Roper, M. C. 2013. A rhamnose-rich $\mathrm{O}$-antigen mediates adhesion, virulence, and host colonization for the xylem-limited phytopathogen Xylella fastidiosa. Mol. Plant-Microbe Interact. 26:676-685.

Cosgrove, D. J. 2000. Loosening of plant cell walls by expansins. Nature 407:321-326.

Cosgrove, D. J. 2017. Microbial expansins. Annu. Rev. Microbiol. 71: 479-497.

Cosgrove, D. J. 2018. Diffuse growth of plant cell walls. Plant Physiol. 176: $16-27$.

Davis, M. J., French, W. J., and Schaad, N. W. 1981. Axenic culture of the bacteria associated with phony disease of peach and plum leaf scald. Curr. Microbiol. 6:309-314.

Dertli, E., Mayer, M. J., and Narbad, A. 2015. Impact of the exopolysaccharide layer on biofilms, adhesion and resistance to stress in Lactobacillus johnsonii FI9785. BMC Microbiol. 15:8.

Deyett, E., Pouzoulet, J., Yang, J. I., Ashworth, V. E., Castro, C., Roper, M. C., and Rolshausen, P.E. 2019. Assessment of Pierce's disease susceptibility in Vitis vinifera cultivars with different pedigrees. Plant Pathol. 68:1079-1087.

Dickison, W. C. 2007. Integrative Plant Anatomy. Harcourt/Academic Press, San Diego, CA.

Fatima, U., and Senthil-Kumar, M. 2015. Plant and pathogen nutrient acquisition strategies. Front. Plant Sci. 6:750.

Freitag, J. H. 1951. Host range of the Pierce's disease virus of grapes as determined by insect transmission. Phytopathology 41:920-934.

Georgelis, N., Nikolaidis, N., and Cosgrove, D. J. 2014. Biochemical analysis of expansin-like proteins from microbes. Carbohydr. Polym. 100:17-23.

Goheen, A. C., and Hopkins, D. L. 1988. Pierce's disease. Pages 44-45 in: Compendium of Grape Diseases. A. C. Goheen and R. C. Pearson, eds. American Phytopathological Society Press, St. Paul, MN.

Gough, C. L., Dow, J. M., Barber, C. E., and Daniels, M. J. 1988. Cloning of two endoglucanase genes of Xanthomonas campestris pv. campestris: Analysis of the role of the major endoglucanase in pathogenesis. Mol. Plant-Microbe Interact. 1:275-281.

Gouran, H., Gillespie, H., Nascimento, R., Chakraborty, S., Zaini, P. A., Jacobson, A., Phinney, B. S., Dolan, D., Durbin-Johnson, B. P., Antonova, E. S., Lindow, S. E., Mellema, M. S., Goulart, L. R., and Dandekar, A. M. 2016. The secreted protease PrtA controls cell growth, biofilm formation and pathogenicity in Xylella fastidiosa. Sci. Rep. 6: 31098.

Guilhabert, M. R., and Kirkpatrick, B. C. 2005. Identification of Xylella fastidiosa antivirulence genes: Hemagglutinin adhesins contribute to $X$. fastidiosa biofilm maturation and colonization and attenuate virulence. Mol. Plant-Microbe Interact. 18:856-868.

Hardy, P. J., and Possingham, J. V. 1969. Studies on translocation of metabolites in the xylem of grapevine shoots. J. Exp. Bot. 20:325-335.

Hématy, K., Cherk, C., and Somerville, S. 2009. Host-pathogen warfare at the plant cell wall. Curr. Opin. Plant Biol. 12:406-413.

Hill, B. L., and Purcell, A. H. 1995. Acquisition and retention of Xylella fastidiosa by an efficient vector, Graphocephala atropunctata. Phytopathology 85:209-212.
Kerff, F., Amoroso, A., Herman, R., Sauvage, E., Petrella, S., Filée, P. Charlier, P., Joris, B., Tabuchi, A., Nikolaidis, N., and Cosgrove, D. J. 2008. Crystal structure and activity of Bacillus subtilis YoaJ (EXLX1), a bacterial expansin that promotes root colonization. Proc. Natl. Acad. Sci. U.S.A. 105:16876-16881.

Koutsoudis, M. D., Tsaltas, D., Minogue, T. D., and von Bodman, S. B. 2006. Quorum-sensing regulation governs bacterial adhesion, biofilm development, and host colonization in Pantoea stewartii subspecies stewartii. Proc. Natl. Acad. Sci. U.S.A. 103:5983-5988.

Kovach, M. E., Elzer, P. H., Hill, D. S., Robertson, G. T., Farris, M. A., Roop, R. M., 2nd, and Peterson, K. M. 1995. Four new derivatives of the broad-host-range cloning vector pBBR1MCS, carrying different antibiotic-resistance cassettes. Gene 166:175-176.

Larner, J. 1960. Other glucosidases. Pages 369-378 in: The Enzymes. P. D. Boyer, H. Lardy, and K. Myrbäck, eds. Academic Press, New York.

Li, W. B., Pria, W. D., Jr., Teixeira, D. C., Miranda, V. S., Ayres, A. J., Franco, C. F., Costa, M. G., He, C. X., Costa, P. I., and Hartung, J. S. 2001. Coffee leaf scorch caused by a strain of Xylella fastidiosa from citrus. Plant Dis. 85:501-505.

Liang, K.-Y., and Zeger, S. L. 1986. Longitudinal data analysis using generalized linear models. Biometrika 73:13-22.

Lionetti, V., Cervone, F., and Bellincampi, D. 2012. Methyl esterification of pectin plays a role during plant-pathogen interactions and affects plant resistance to diseases. J. Plant Physiol. 169:1623-1630.

Loescher, W. H., McCamant, T., and Keller, J. D. 1990. Carbohydrate reserves, translocation, and storage in woody plant roots. HortScience 25:274-281.

Matsumoto, A., Young, G. M., and Igo, M. M. 2009. Chromosome-based genetic complementation system for Xylella fastidiosa. Appl. Environ. Microbiol. 75:1679-1687.

McCullagh, P., and Nelder, J. A. 1989. Generalized Linear Models, 2nd ed. Chapman \& Hall, London.

McElrone, A. J., Sherald, J. L., and Forseth, I. N. 2001. Effects of water stress on symptomatology and growth of Parthenocissus quinquefolia infected by Xylella fastidiosa. Plant Dis. 85:1160-1164.

McElrone, A. J., Sherald, J. L., and Forseth, I. N. 2003. Interactive effects of water stress and xylem-limited bacterial infection on the water relations of a host vine. J. Exp. Bot. 54:419-430.

Mohammadi, M., Burbank, L., and Roper, M. C. 2012. Pantoea stewartii subsp. stewartii produces an endoglucanase that is required for full virulence in sweet corn. Mol. Plant-Microbe Interact. 25: 463-470.

Mollenhauer, H. H., and Hopkins, D. L. 1974. Ultrastructural study of Pierce's disease bacterium in grape xylem tissue. J. Bacteriol. 119: 612-618.

Newman, K. L., Almeida, R. P. P., Purcell, A. H., and Lindow, S. E. 2004 Cell-cell signaling controls Xylella fastidiosa interactions with both insects and plants. Proc. Natl. Acad. Sci. U.S.A. 101:1737-1742.

Nikolaidis, N., Doran, N., and Cosgrove, D. J. 2014. Plant expansins in bacteria and fungi: Evolution by horizontal gene transfer and independent domain fusion. Mol. Biol. Evol. 31:376-386.

Pérez-Donoso, A. G., Sun, Q., Roper, M. C., Greve, L. C., Kirkpatrick, B. and Labavitch, J. M. 2010. Cell wall-degrading enzymes enlarge the pore size of intervessel pit membranes in healthy and Xylella fastidiosainfected grapevines. Plant Physiol. 152:1748-1759.

Pieretti, I., Royer, M., Barbe, V., Carrere, S., Koebnik, R., Couloux, A., Darrasse, A., Gouzy, J., Jacques, M. A., Lauber, E., and Manceau, C. 2012. Genomic insights into strategies used by Xanthomonas albilineans with its reduced artillery to spread within sugarcane xylem vessels. BMC Genomics 13:658.

Popeijus, H., Overmars, H., Jones, J., Blok, V., Goverse, A., Helder, J., Schots, A., Bakker, J., and Smant, G. 2000. Degradation of plant cell walls by a nematode. Nature 406:36-37.

Purcell, A. H. 1986. Pierce's disease. Pages 62-69 in: Grape Pest Management. D. L. Flaherty, ed. Cooperative Extension, University of California, Division of Agriculture and Natural Resources, Oakland, CA.

Purcell, A. H., and Saunders, S. R. 1999. Fate of Pierce's disease strains of Xylella fastidiosa in common riparian plants in California. Plant Dis. 83: $825-830$

Rapicavoli, J., Ingel, B., Blanco-Ulate, B., Cantu, D., and Roper, C. 2018. Xylella fastidiosa: An examination of a re-emerging plant pathogen. Mol. Plant Pathol. 19:786-800.

Rendueles, O., Kaplan, J. B., and Ghigo, J. M. 2013. Antibiofilm polysaccharides. Environ. Microbiol. 15:334-346.

Roberts, D. P., Denny, T. P., and Schell, M. A. 1988. Cloning of the $e g l$ gene of Pseudomonas solanacearum and analysis of its role in phytopathogenicity. J. Bacteriol. 170:1445-1451. 
Roper, M. C. 2006. The Characterization and Role of Xylella fastidiosa Plant Cell Wall Degrading Enzymes and Exopolysaccharide in Pierce's Disease of Grapevine. University of California, Davis, CA.

Roper, M. C., Greve, L. C., Warren, J. G., Labavitch, J. M., and Kirkpatrick, B. C. 2007. Xylella fastidiosa requires polygalacturonase for colonization and pathogenicity in Vitis vinifera grapevines. Mol. Plant-Microbe Interact. 20:411-419.

Saile, E., McGarvey, J. A., Schell, M. A., and Denny, T. P. 1997. Role of extracellular polysaccharide and endoglucanase in root invasion and colonization of tomato plants by Ralstonia solanacearum. Phytopathology $87: 1264-1271$

Saponari, M., Boscia, D., Nigro, F., and Martelli, G. P. 2013. Identification of DNA sequences related to Xylella fastidiosa in oleander, almond and olive trees exhibiting leaf scorch symptoms in Apulia (southern Italy). J. Plant Pathol. 95:659-668.

Scheller, H. V., and Ulvskov, P. 2010. Hemicelluloses. Annu. Rev. Plant Biol. 61:263-289.

Schuenzel, E. L., Scally, M., Stouthamer, R., and Nunney, L. 2005. A multigene phylogenetic study of clonal diversity and divergence in North American strains of the plant pathogen Xylella fastidiosa. Appl. Environ. Microbiol. 71:3832-3839.

Simpson, A. J. G., Reinach, F. C., Arruda, P., Abreu, F. A. D., Acencio, M., Alvarenga, R., Alves, L. M. C., Araya, J. E., Baia, G. S., Baptista, C. S., Barros, M. H. D., Bonaccorsi, E. D., Bordin, S., Bové, J. M., Briones, M. R. S., Bueno, M. R. P., Camargo, A. A., Camargo, L. E. A., Carraro, D. M., Carrer, H., Colauto, N. B., Colombo, C., Costa, F. F., Costa, M. C. R., Costa-Neto, C. M., Coutinho, L. L., Cristofani, M., Dias-Neto, E., Docena, C., El-Dorry, H., Facincani, A. P., Ferreira, A. J. S., Ferreira, V. C. A., Ferro, J. A., Fraga, J. S., França, S. C., Franco, M. C., Frohme, M., Furlan, L. R., Garnier, M., Goldman, G. H., Goldman, M. H. S., Gomes, S. L., Gruber, A., Ho, P. L., Hoheisel, J. D., Junqueira, M. L., Kemper, E. L., Kitajima, J. P., Krieger, J. E., Kuramae, E. E., Laigret, F., Lambais, M. R., Leite, L. C. C., Lemos, E. G. M., Lemos, M. V. F., Lopes, S. A., Lopes, C. R., Machado, J. A., Machado, M. A., Madeira, A. M. B. N., Madeira, H. M. F., Marino, C. L., Marques, M. V., Martins, E. A. L., Martins, E. M. F., Matsukuma, A. Y., Menck, C. F. M., Miracca, E. C., Miyaki, C. Y., Monteriro-Vitorello, C. B., Moon, D. H., Nagai, M. A., Nascimento, A. L. T. O., Netto, L. E. S., Nhani, A., Jr., Nobrega, F. G., Nunes, L. R., Oliveira, M. A., de Oliveira, M. C., de Oliveira, R. C., Palmieri, D. A., Paris, A., Peixoto, B. R., Pereira, G. A. G., Pereira, H. A., Jr., Pesquero, J. B., Quaggio, R. B., Roberto, P. G., Rodrigues, V., de M Rosa, A. J., de Rosa, V. E., Jr., de Sá, R. G., Santelli, R. V., Sawasaki, H. E., da Silva, A. C., da Silva, A. M., da Silva, F. R., da Silva, W. A., Jr., da Silveira, J. F., Silvestri, M. L., Siqueira, W. J., de Souza, A. A., de Souza, A. P., Terenzi, M. F., Truffi, D., Tsai, S. M., Tsuhako, M. H., Vallada, H., Van Sluys, M. A., Verjovski-Almeida, S., Vettore, A. L., Zago, M. A., Zatz, M., Meidanis, J., and Setubal, J. C. 2000. The genome sequence of the plant pathogen Xylella fastidiosa. Nature 406: 151-159.

Stevenson, J. F., Matthews, M. A., and Rost, T. L. 2004. Grapevine susceptibility to Pierce's disease I: Relevance of hydraulic architecture. Am. J. Enol. Vitic. 55:228-237.

Stevenson, J. F., Matthews, M. A., and Rost, T. L. 2005. The developmental anatomy of Pierce's disease symptoms in grapevines: Green islands and matchsticks. Plant Dis. 89:543-548.
Sun, Q., Greve, L. C., and Labavitch, J. M. 2011. Polysaccharide compositions of intervessel pit membranes contribute to Pierce's disease resistance of grapevines. Plant Physiol. 155:1976-1987.

Sun, Q., Sun, Y., and Juzenas, K. 2017. Immunogold scanning electron microscopy can reveal the polysaccharide architecture of xylem cell walls. J. Exp. Bot. 68:2231-2244.

Tancos, M. A., Lowe-Power, T. M., Peritore-Galve, F. C., Tran, T. M., Allen, C., and Smart, C. D. 2018. Plant-like bacterial expansins play contrasting roles in two tomato vascular pathogens. Mol. Plant Pathol. 19:1210-1221.

Thorne, E. T., Stevenson, J. F., Rost, T. L., Labavitch, J. M., and Matthews, M. A. 2006a. Pierce's disease symptoms: Comparison with symptoms of water deficit and the impact of water deficits. Am. J. Enol. Vitic. 57:1-11.

Thorne, E. T., Young, B. M., Young, G. M., Stevenson, J. F., Labavitch, J. M., Matthews, M. A., and Rost, T. L. 2006b. The structure of xylem vessels in grapevine (Vitaceae) and a possible passive mechanism for the systemic spread of bacterial disease. Am. J. Bot. 93:497-504.

Tovar-Herrera, O. E., Rodríguez, M., Olarte-Lozano, M., SampedroGuerrero, J. A., Guerrero, A., Pinto-Cámara, R., Alvarado-Affantranger, X., Wood, C. D., Moran-Mirabal, J. M., Pastor, N., Segovia, L., and Martínez-Anaya, C. 2018. Analysis of the binding of expansin Ex11, from Pectobacterium carotovorum, to plant xylem and comparison to EXLX1 from Bacillus subtilis. ACS Omega 3:7008-7018.

Tyree, M. T., and Zimmermann, M. H. 2002. Hydraulic architecture of whole plants and plant performance. Pages 175-214 in: Xylem Structure and the Ascent of Sap. Springer-Verlag, Berlin.

Van Sluys, M. A., de Oliveira, M. C., Monteiro-Vitorello, C. B., Miyaki, C. Y., Furlan, L. R., Camargo, L. E. A., da Silva, A. C. R., Moon, D. H., Takita, M. A., Lemos, E. G. M., Machado, M. A., Ferro, M. I. T., da Silva, F. R., Goldman, M. H. S., Goldman, G. H., Lemos, M. V. F., ElDorry, H., Tsai, S. M., Carrer, H., Carraro, D. M., de Oliveira, R. C., Nunes, L. R., Siqueira, W. J., Coutinho, L. L., Kimura, E. T., Ferro, E. S., Harakava, R., Kuramae, E. E., Marino, C. L., Giglioti, E., Abreu, I. L., Alves, L. M. C., do Amaral, A. M., Baia, G. S., Blanco, S. R., Brito, M. S., Cannavan, F. S., Celestino, A. V., da Cunha, A. F., Fenille, R. C., Ferro, J. A., Formighieri, E. F., Kishi, L. T., Leoni, S. G., Oliveira, A. R., Rosa, V. E., Jr., Sassaki, F. T., Sena, J. A. D., de Souza, A. A., Truffi, D., Tsukumo, F., Yanai, G. M., Zaros, L. G., Civerolo, E. L., Simpson, A. J. G., Almeida, N. F., Jr., Setubal, J. C., and Kitajima, J. P. 2003. Comparative analyses of the complete genome sequences of Pierce's disease and citrus variegated chlorosis strains of Xylella fastidiosa. J. Bacteriol. 185:1018-1026.

Varela, L. G. 1996. Pierce's Disease in the North Coast. University of California Cooperative Extension \& Statewide IPM Project: 1 Y11. Integrated Pest Management, University of California, Agriculture and Natural Resources, Davis, CA.

Walker, D. S., Reeves, P.J., and Salmond, G. P. 1994. The major secreted cellulase, CelV, of Erwinia carotovora subsp. carotovora is an important soft rot virulence factor. Mol. Plant-Microbe Interact. 7:425-425.

Wang, P., Lee, Y., Igo, M. M., and Roper, M. C. 2017. Tolerance to oxidative stress is required for maximal xylem colonization by the xylem-limited bacterial phytopathogen, Xylella fastidiosa. Mol. Plant Pathol. 18:990-1000.

Ward, O. P., Moo-Young, M., and Venkat, K. 1989. Enzymatic degradation of cell wall and related plant polysaccharides. Crit. Rev. Biotechnol. 8: 237-274. 